\title{
LA-8795-GEOL
}
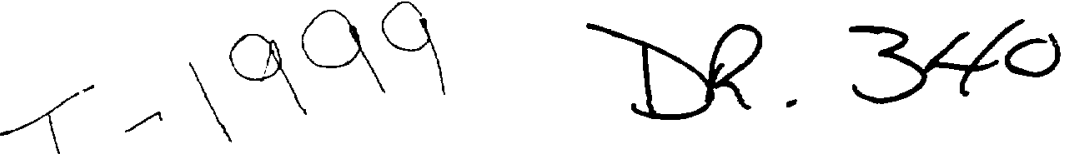

GEOLOGIC EVOLUTION OF THE JEMEZ MOUNTAINS AND THEIR POTENTIAL

FOR FUTURE VOLCANIC ACTIVITY

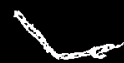




\section{Geologic Evolution of the Jemez Mountains and Their Potential for Future Volcanic Activity}

by

Barry W. Burton

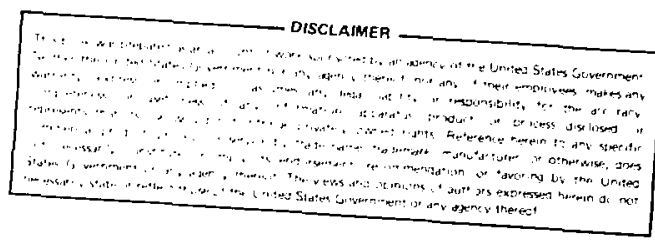

NOTICE

PORTIONS OF THIS REPORT ARE ILLEGISAE $A$

has been rearoduced from the best availot copy to permit the broadest possible avall ability. 


\title{
GEOLOGIC EVOLUTION OF THE JEMEZ MOUNTAINS AND THEIR POTENTIAL FOR FUTURE VOLCANIC ACTIVITY
}

\author{
by
}

Barry W. Burton

\begin{abstract}
Geophysical and geochemical data and the geologic history of the Ric Grande rift and the vicinity of the Jemez Mountains are summarized to determine the probability of future volcanic activity in the Los Alamos, New Mexico area. The apparent cyclic nature of volcanism in the Jemez Mountains may be related to intermittent thermal inputs into the volcanic system beneath the region. The Jemez lineament, an alignment of late Cenozoic volcanic centers that crosses the rift near Los Alamos, has played an important role in the volcanic evolution of the Jemez Mountains. Geophysical data suggest that there is no active shallow magma body beneath the Valles caldera, though magma probably exists at about $15 \mathrm{~km}$ beneath this portion of the rift. The rate of volcanism in the Jemez Mountains during the last 10 million years has been $5 \times$ $10^{-9} / \mathrm{km}^{2} / \mathrm{yr}$. Lava or ash flows overriding Laboratory radioactive waste disposal sites would have little potential to release radionuclides to the environment. The probability of a new volcano intruding close enough to a radioactive waste disposal site to effect radionuclide release is $2 \times 10^{-7} / \mathrm{yr}$.
\end{abstract}

\section{INTRODUCTION}

The Jemez Mountains volcanic pile in northcentral New Mexico lies astride the western fault margin of the Rio Grande rift, ${ }^{12,3}$ an $800-\mathrm{km}$-long intracontinental rift zone that extends southward from southern Colorado, through New Mexico, into northern Mexico (Fig. 1). ${ }^{45,6}$ In the vicinity of the Jemez Mountains the rift is crossed by the Jemez (or Springerville-Raton) lineament, a northeast-trending belt of late Cenozoic volcanic centers. ${ }^{3,5,7}$ The mountains consist of volcanic rocks erupted from many vents during the last 10 million years (Myr), culminating in two major pyroclastic eruptions that deposited more than $600 \mathrm{~km}^{3}$ of rhyolite ash and pumice as an apron around the mountains. ${ }^{2,8.9 .10}$ This ignimbrite unit-the Bandelier Tuff-has a maximum thickness of $300 \mathrm{~m}$ and forms the Pajarito and Jemez
Plateaus on the eastern and western flanks of the mountains, respectively. Los Alamos National Laboratory is located on the Pajarito Plateau, which is dissected into a series of east- to southeast-trending narrow mesas, separated by deeply incised canyons (Fig.2).

For more than 35 years radioactive wastes have been disposed of in engineered pits, trenches, shafts, and absorption beds excavated in the Bandelier Tuff on the mesa tops (Fig. 3). ${ }^{11}$ Because of the long time period over which these wastes remain hazardous, many ongoing research and surveillance programs are conducted by the Laboratory's Life Science and Health Divisions to ensure the integrity of these. disposal sites. Natural events, however, may result in radioactivity being released to the environment. These include chronic erosion, earthquakes, meteorite impacts, tornadoes, water-related release caused by climatologic changes, and volcanic 


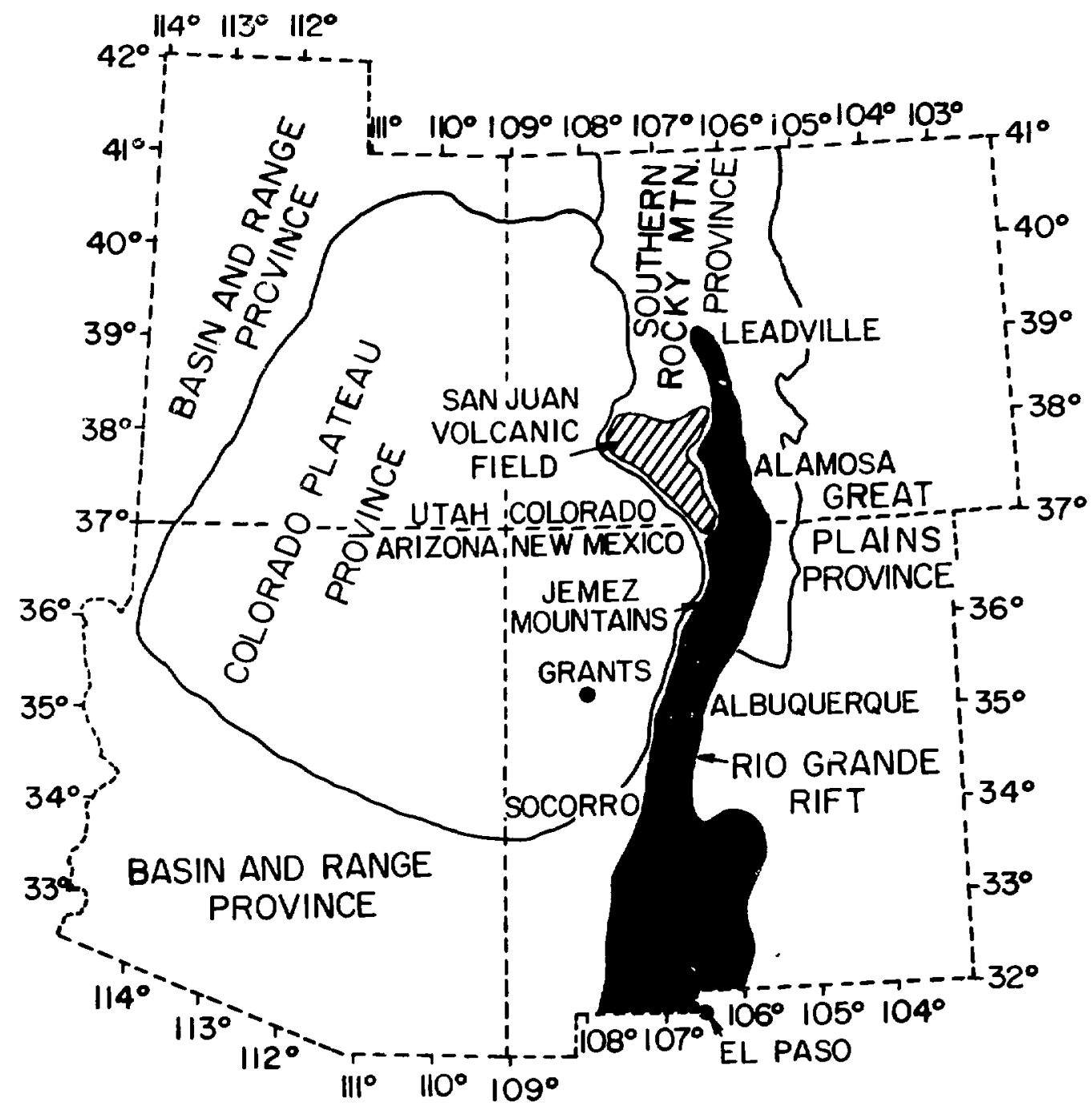

Fig. 1. Major geomorphic provinces in the Southwestern United States.

eruptions. Probability estimates for the occurrence at Los Alamos of the first five of these potential release mechanisms have been reported in several earlier studies. ${ }^{12-18}$ This report discusses evidence to support estimates for continued volcanic activity in the Jemez Mountains that may affect Laboratory radioactive waste disposal sites.

Because of the acute and complex nature of volcanism, it is necessary to draw on data from nearly every aspect of the earth sciences to derive reasonable estimates. Important factors include the geological and structural history, petrology, seismicity, terrestrial heat flow, and current geothermal activity of the Rio Grande rift and Jemez Mountains.

\section{GEOLOGIC HISTORY OF THE RIO GRANDE RIFT}

To better understand the causes of volcanism in the Jemez Mountains, it may be helpful to summarize the geologic events leading to their formation. The volcanic evolution of the Jemez Mountains is a direct result of the tectonic forces that formed the Rio Grande rift. Likewise, the rift is one consequence of the dynamic large-scale plate tectonic environment in which the geology of the western United States was (and is still being) shaped. The earth's crust (and almost certainly the uppermost layer of the mantle) is broken into a series of large and small plates that move back and forth across 


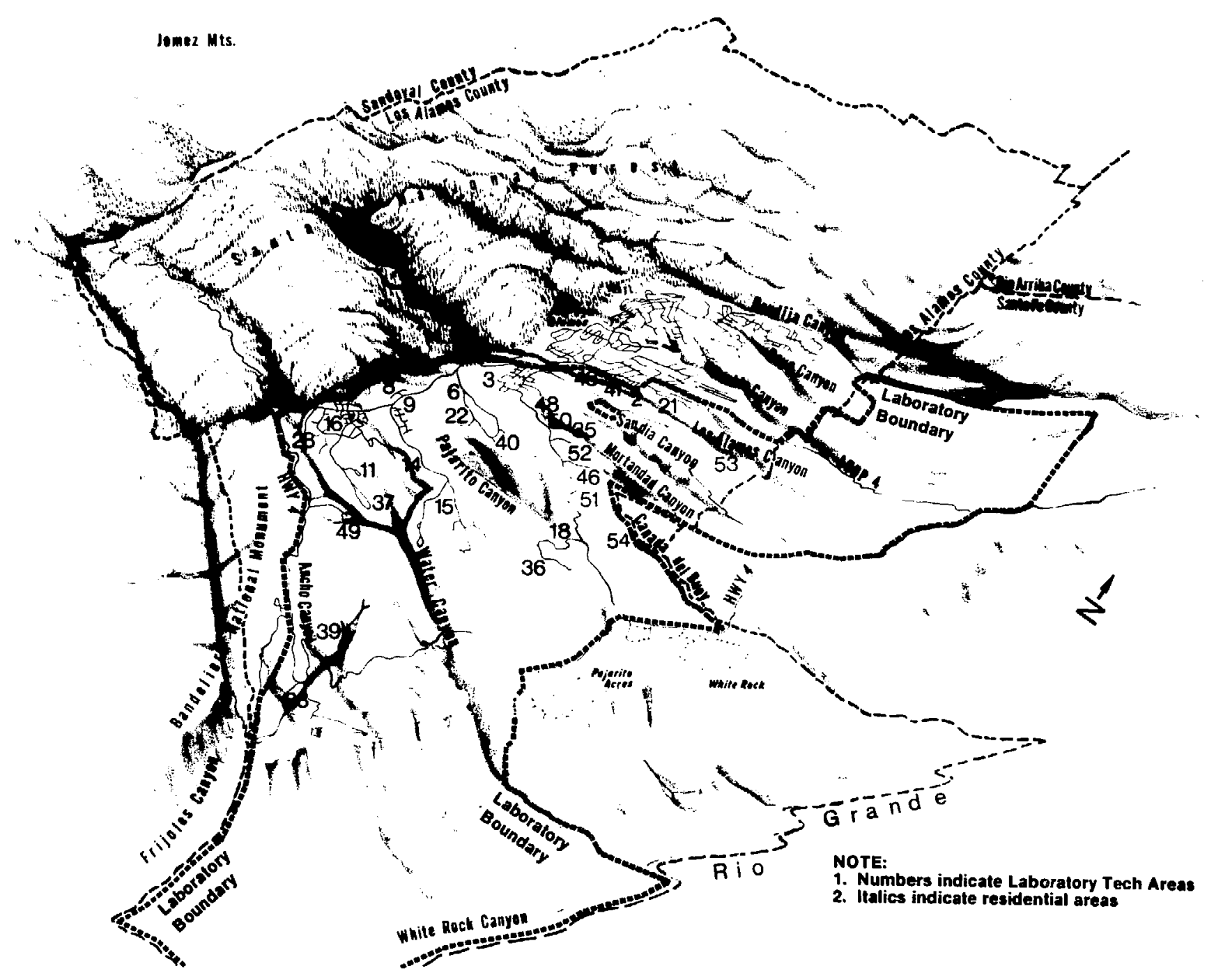

Fig. 2. Topography of the Los Alamos, New Mexico, area. 


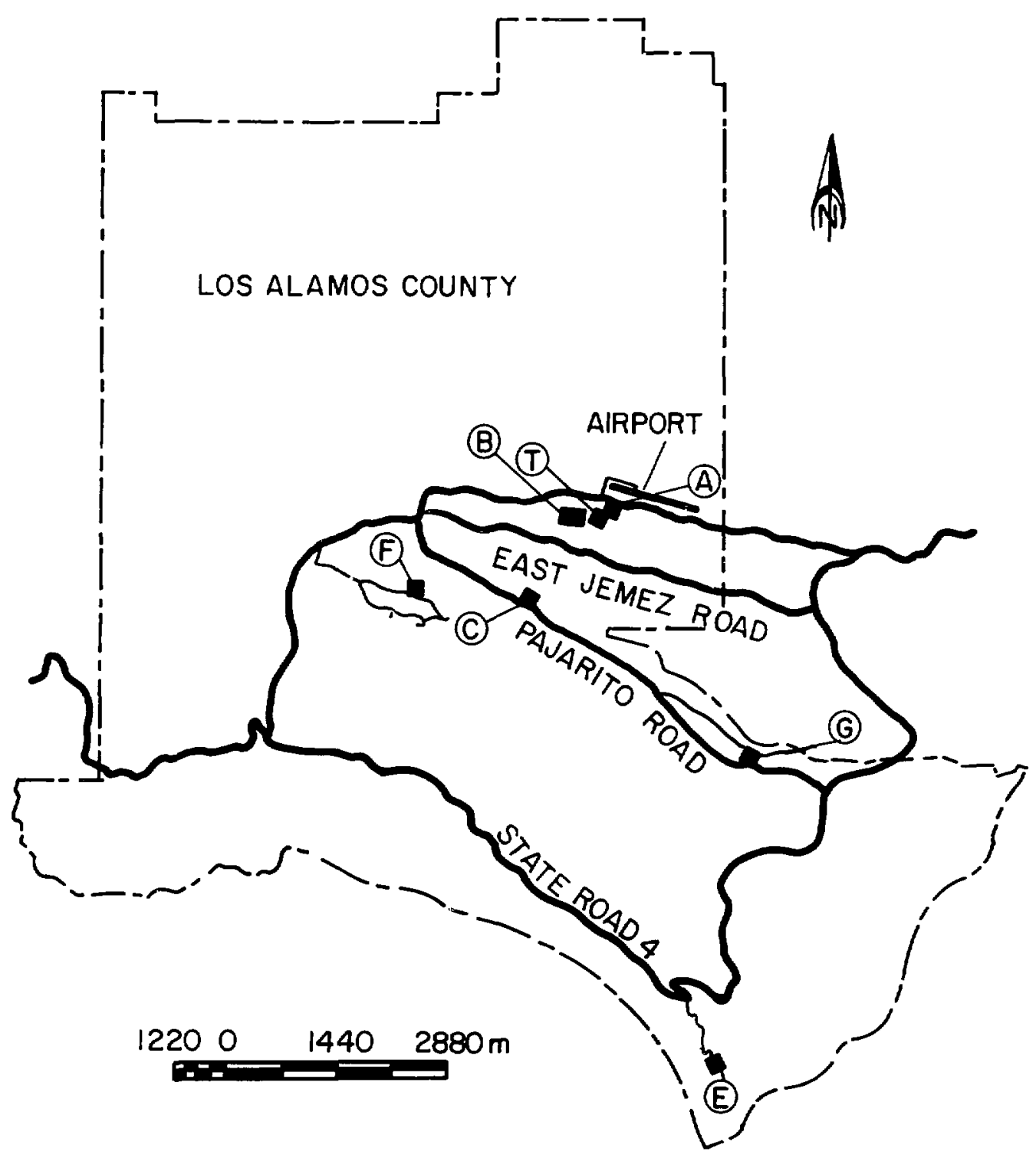

Fig. 3. Map of Los Alamos radioactive waste disposal sites.

the planet at average rates of a few tens of millimeters per year. The driving force for these movements is not well understood, but the plates probably ride on thermal convection cells that occur in the upper part of the mantle. When plates converge, one is usually overridden by the other, with the formation of a subduction zone. Magmas produced by partial melting in the descending slab may rise to the surface as a broad zone of volcanic centers, called a volcanic arc. At the trailing edges of global plates, such as the mid-Atlantic Ridge, new magmas rise to the surface, filling in the void created by the diverging plates. If these spreading centers occur within continents, they may form intracontinental rift zones, such as the East African and Rio Grande rifts.

Global plate collisions of the west coast of the continent resulted in regional extension, widespread volcanism, and transform and block faulting throughout much of the western United States during the last half of 
the Cenozoic Era (see Appendix A for the geologic time scale used in this report). A major part of the deformation may be envisioned as resulting from the interactions between several semi-rigid subplates behind the major North American plate boundary. ${ }^{19}$

In the early Cenozoic the western margin of the United States was a trench. The North American plate, carrying the continent, was separated from the large Pacific plate to the west by the smaller oceanic Farallon plate. The boundary between the Pacific and Farallon plates was a spreading oceanic ridge. Because of the relative counterclockwise rotation of the continent, the Farallon plate was being subducted beneath North America at an oblique angle. ${ }^{20,21}$ Plate convergence was rapid $(100 \mathrm{~mm} / \mathrm{yr})$, giving a shallow dip to the subducting slab, which extended far inland beneath the continent. Calc-alkalic magmas produced by partial melting in the descending slab ascended and erupted to the surface as a volcanc arc, a broad zone of volcanic centers. The boundary of the volcanic arc was east of the present Rio Grande rift. ${ }^{19}$

The subducted Farallon plate continued to be consumed at the trench until, about $32 \mathrm{Myr}$ ago, it broke apart off what is now Baja California and pieces of the spreading ridge to the west began to collide with the trench. ${ }^{20}$ The trench became congested, reducing the rate of convergence. The angle of the descending slab steepened and the volcanic arc began to retreat westward. ${ }^{19}$ Northeast-southwest directed tensional stresses resulted in extensional failure throughoui much of the southwestern United States. ${ }^{19}$ In the Rio Grande rift area, still within the arc, rapid spreading produced many closely spaced normal faults, fault block rotation, and eruption of basaltic adesite and high-silica rhyolite at shallow levels. ${ }^{19,22}$

The Rio Grande rift evolved along old crustal flaws within the southern Rocky Mountains (Fig. 1). ${ }^{4}$ This latter is a major north-trending zone of weakness that had developed during periods of mourtain building in the late Paleozoic and again in the late Cretaceous and early Tertiary. Twenty-six-million-year-old mafic lava flows and volcanic ash are found interbedded with alluvium in the rif, indicating that the crust subsided in response to regonal extension, forming a trough by that time. As the rift continued to open, it broke en echelon across northeast- and north-northwest-trending lineaments (transverse structure) in the Precambrian basement rock, forming a series of basins that were successively offset to the right. These basins were downfaulted along opposite margins in alternating succession, as shown in Fig. 4.

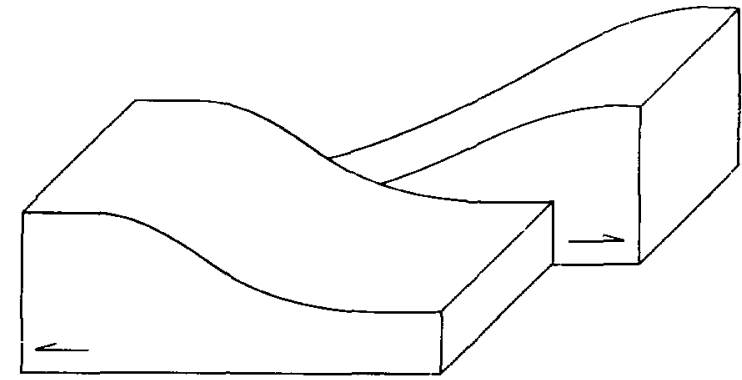

Fig. 4. Schematic diagram showing the relationship of basins adjoining a transverse structure.

Thus, as basins across a lineament plunged in opposite directions, the brittle surface rocks were pivoted in a scissors-like fashion, while rocks at depth were subjected to lateral shear." Strein developing at shallow levels was relieved by a complex series of interlocking normal faults rather than by simple strike-slip faulting. "The lineaments extend to great depth and probably intersect the upper mantle beneath the rift, allowing magma to migrate upward and collect in shallow crustal reservoirs. ${ }^{4,23,24}$

By about $20 \mathrm{Myr}$ ago, the westward-retreating volcanic arc had reached western Arizona and Nevada; east of the arc, a reduced spreading rate resulted in a period of volcanic quiescence. ${ }^{19}$ This condition continued until about $17 \mathrm{Myr}$ ago, when normal faulting and crustal rifting was renewed throughout much of the Basin and Range and Colorado Plateau provinces (Fig. 1), locally accompanied by voluminous basaltic volcanism. ${ }^{19}$

At the continental margin, the collision of the southern end of the spreading ridge with the trench had brought the North American and Pacific plates into direct contact, forming a rise-trench-transform fault (RTF) triple junction. ${ }^{20}$ Because of its geometric configuration, the triple junction was spatially unstable, so that interactions between the two plates caused it to migrate progressively northward, lengthening the newly formed San Andreas transform fault. ${ }^{19,20}$ Transform faults $i$ re tectonic plate boundaries, along which movement is lateral (strike-slip) rather than convergent or divergent. Fault piane solutions for faults formed within the continent indicate that sometime between 9 and $7 \mathrm{Myr}$ ago the direction of tensional stresses rotated from northeast to east. ${ }^{19}$

The hiatus in volcanism lasted longer in the Rio Grande area than in the Basin and Range and Colorado Plateau provinces: from 20 until $13 \mathrm{Myr}$ ago., ${ }^{49}$ Then activity began to increase slowly, initially in the Socorro, 
New Mexico area and Jemez Mountains, where the rift intersects the Morenci and Jemez lineaments, respectively. In the rift south of Socorro, volcanism changed from the earlier hasaltic andesite and high-silica rhyolite with high initial ${ }^{87} \mathrm{Sr} /{ }^{86} \mathrm{Sr}$ ratios to basalt and rhyolite in which these ratios are low. ${ }^{4}$ These ratios are suggestive of the age of the parent material from which magmas are derived. This transition from high to low suggests the earth's mantle was rising beneath the rift, forming a mantle diapir beneath the thinning lithosphere. Supportive evidence is provided by radiogenic lead data for the same area. ${ }^{4}$ Source areas for magmas north of Socorro seem to have remained in the lithosphere during this period. ${ }^{4,5}$

Between 7 and $4 \mathrm{Myr}$ ago the direction of tensional stresses in the northern Basin and Range and southern Rocky Mountain provinces was again rotated, this time to the west-northwest and northwest. $^{19}$ Strong epeirogenic uplift $(\sim 1100 \mathrm{~m})$ in the southern Rocky Mountains was probably caused by a continuance of $\mathrm{r}_{\text {i antle upwelling. }}{ }^{4}$ Block faulting occurred in the rift and a pronounced increase in bimodal volcanism (basalt and rhyolite, with little occurrence of intermediate rock types) began about $5 \mathrm{Myr}$ ago along the Jemez lineament and in the Taos Plateau. ${ }^{4.7,25}$ Sometime between 5 and 3 Myr ago the ancertral Rio Grande was formed.,26 Extensive geomorphic surfaces were leveled by fluvial processes, then covered by basalt flows. Stream capture of the Rio Grande near El Paso. Texas, in the middle Pleistocene, resulted in lowering of base level and formation of present dissected mesas. ${ }^{4}$ Regional uplift continued after $4 \mathrm{Myr}$ ago at a reduced rate. ${ }^{4}$ The estimated average spreading rate in the rift during the last $30 \mathrm{Myr}$ is 0.2 to $0.3 \mathrm{~mm} / \mathrm{yr}^{1,25}$

The Rio Grande rift may be informally divided into three distinct parts. In the northern seciiun, between Leadville and Alamosa, Colorado (Fig. 1) rifting began about $27 \mathrm{Myr}$ ago. The rift in this region parallels the north-northwest structural trend of the southern Rocky Mountains and only a minor amount of contemporaneous volcanics are found in these northern basins.

The central rift, from Alamosa, Colorado, southward to Socorro, New Mexico, is a north-northeast-trending succession of en echelon basins separated by transverse structures. The basement complex in this region consists of 1300- to 1800-Myr-old Precambrian igneous, metaigneous, and metasedimentary rocks. ${ }^{27}$ The early history of this part of the rift was marked by relatively limited volcanism, occurring mostly in the Taos, New Mexico area; after $13 \mathrm{Myr}$ ago, bimodal volcanism was voluminous, sspecially during the last $5 \mathrm{Myr}$, along the Jemez lineament. ${ }^{4,7,25}$

The southern part of the rift began to open about 32 Myr ago. ${ }^{4}$ In the Socorro area, the rift is about 2.5 times wider than to the north, breaking up into a series of north-trending parallel basins. The rift bifurcates just north of Socorro and a subsidiary limb, the San Augustin rift, extends southwestward along the Morenci lineament into Arizona, forming what is sometimes called the Socorro Triangle. The main rift begins to lose surface definition toward the south and becomes topographically indistinguishable from the southern Basin and Range province, which it crosses. Geophysical data, especially heat flow measurements, suggest that the rift continues into northern Mexico. ${ }^{6,28}$

The Rio Grande rift was formed as a result of large-scale plate tectonic forces that have been active throughout the western United States. The rift evolved along old crustal flaws in the southern Rocky Mountains, opening about $32 \mathrm{Myr}$ ago, first in the south and extending progressively northward. After about $13 \mathrm{Myr}$ ago, mantle upwelling resulted in strong regional uplift, with block faulting and voluminous bimodal volcanism. The central rift is a north-northeast-trending series of en echelon basins, separated ty transverse structures. One of these, the Jemez lineament, crosses the rift in the vicinity of the Jemez Mountains. Volcanism along the Jemez lineament has been especially active in the last 5 Myr.

\section{RELATIONSHIP BETWEEN VOLCANISM AND GEOLOGIC STRUCTURE}

To determine the likely future of volcanic activity in the Jemez Mountains it is important to understand the causes of magmatism in the past. Petrologic evidence suggests that volcanic rocks in the vicinity of the mountains are formed from magmas derived from two different sources. The location of the Jemez Mountains at the western edge of the Española basin is likely controlled by the intersection of the rift with the Jemez lineament. This section presents a review of the geologic structure within that zone of intersection and the probable sources of magmas. The relationship between geologic structure and volcanism will be discussed.

\section{A. Structure of the Española Basin}

The basins in the central part of the Rio Grande rift are offset from one another in a northeasterly direction 
(Fig. 5). The Española basin, 35 to $65 \mathrm{~km}$ long and 65 to $85 \mathrm{~km}$ wide, is separated from the San Luis basin and the Taos Plateau volcanic field on the north by a basement ridge, and from the Santo Domingo subbasin on the south by the northwest-trending La Bajada fault; the basin is bounded on the east by the Sangre de Cristo Mountains and is strongly faulted against the Nacimiento Uplift on the west. ${ }^{26}$ All but the southern borders are characterized by steep gravity gradients. ${ }^{29}$ The eastern margin of the basin is probably not fault-bounded. Most of the contacts between the Sangre de Cristo Mountains and the Miocene/Pliocene Santa Fe Group rocks in the basin are depositional, though some faults (both synthetic and antithetic) do occur. ${ }^{30}$ At the mountain front, Santa Fe beds often dip 8 to $30^{\circ}$ westward, becoming shallower $\left(<8^{\circ}\right)$ within the basin. ${ }^{29,30}$ This homoclinal dip, also evidenced in gravity data for the area, ${ }^{29}$ is shown schematically in Fig. 4. There are many small high-angle normal faults in the eastern half of the basin, but displacements are more commonly down-tothe-east. ${ }^{26.31}$

The Velarde graben is a structural trough, with more than $360 \mathrm{~m}$ of stratigraphic offset, that extends in a northeasterly direction beneath the central part of the
Española basin. ${ }^{26.29}$ The graben is $8 \mathrm{~km}$ wide at the northern end of the basin and broadens to about $30 \mathrm{~km}$ at the southern end. ${ }^{26}$ As it crosses the Pajarito Plateau, its westem boundury is the Pajarito fault (Fig. 6), which brings Pleistocene Bandelier Tuff against pre-rift rocks of Eccene age. ${ }^{26}$ Movement along boundary faults of the Velarde graben may have begun as early as late Miocene, but most of the downdropping occurred between 5 and $3 \mathrm{Myr}$ ago. ${ }^{26}$ The smaller El Alto graben, just to the west of the Velarde graben, underlies much of the eastern side of the Jemez Mountains. ${ }^{29}$

Basin fill deposits are sedimentary and volcanic formations ranging in age from Eocene to Holocene, but Santa Fe Group rocks are the major constituent. ${ }^{26,31}$ Gravity data suggest that the thickness of the depositional sequence in the basin exceeds $2150 \mathrm{~m} .^{26}$

\section{B. Major Faults in the Jemez Mountains}

The Jemez Mountains are located astride the downfaulted westernmost edge of the Española basin. Thus, much of this boundary is concealed bcneath Pliocene and Pleistocene volcanic rocks. The mountains are cut by three major north- to northeast-trending fault zones:

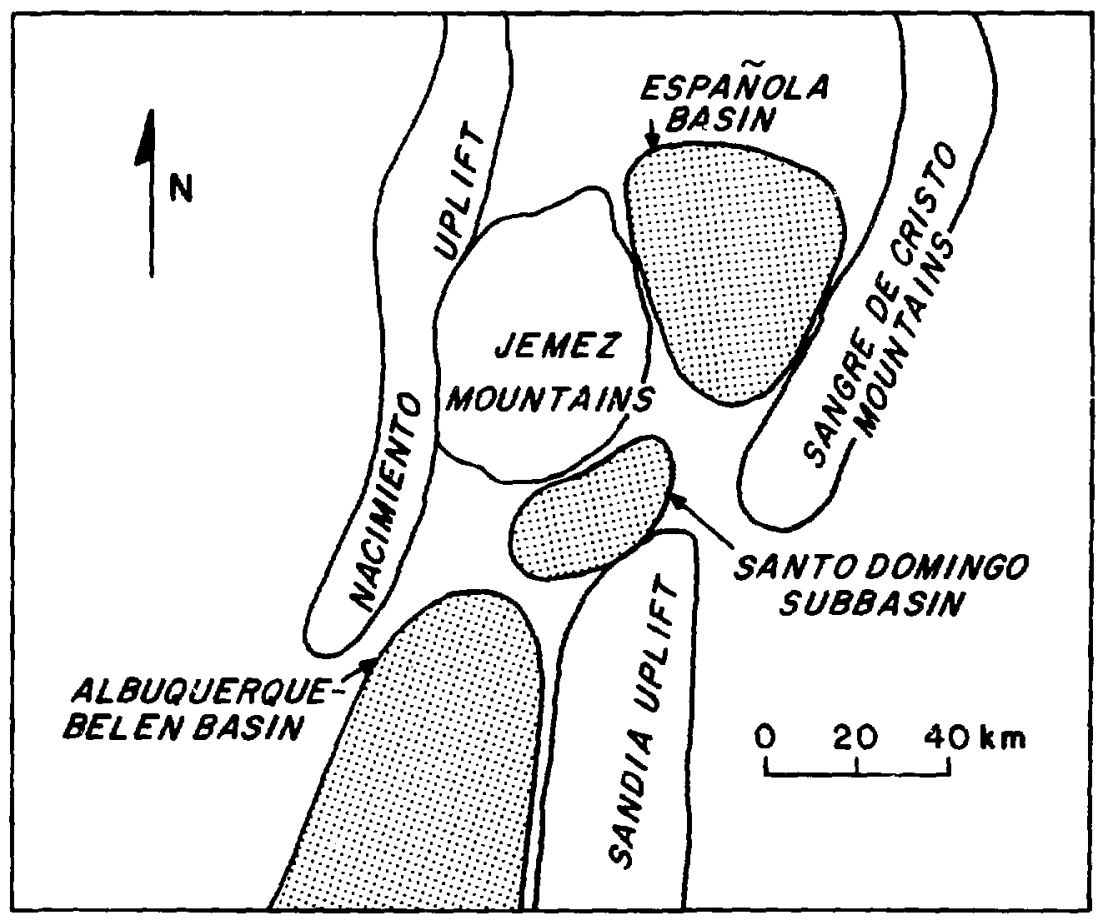

Fig. 5. Generalized map of part of the central Rio Grande rift. 
the Jemez fault zone in the southwestern part of the mountains, the San Felipe fault zone along the southern axis, and the Pajarito fault zone along the eastern side (Fig. 6).

\section{Jemez Fault Zone}

The Jemez fault zone juxtaposes Santa Fe beds with Mesozoic rocks of the Nacimiento Uplift and displaces Permian to Quaternary deposits., ${ }^{2,9,26}$ The northeastern end of the fault zone, as it follows San Diego Canyon, cannot be traced into the Valles caldera, but its siignment with a post-caldera graben suggests that the position of the latter may be controlled by fauli. $n_{1}^{\prime}$ the Jemez system. ${ }^{2}$ Though uplift of the Nacimiento Mountains to the west is Laramide (late Cretaceous/early Tertiary) in age, the Jemez fault zone was formed by rifting processes in the middle Tertiary. ${ }^{1}$ No measurable movement has occurred along the Jemez fault during the last $0.1 \mathrm{Myr}$, as the Battleship Rock member of the Valles Rhyolite i, not offset. ${ }^{2.9}$

\section{San Felipe Fault Zone}

The San Felipe fault zone occurs as a broad band (up to $10 \mathrm{~km}$ wide) of high-angle normal faults that cross Santa Ana Mesa and extend northward to the Valles caldera, displacing the older volcanic rocks and sediments in the southern part of the mountains. ${ }^{2.9}$ The Bandelier Tuff is not offset by these faults, suggesting the. they may no longer be active or that the recurrence interval is very long. ${ }^{32}$ The Valles caldera is located at the intersection of the Jemez and San Felipe fault zones and its position may be controlled by them. ${ }^{32}$

\section{Pajarito Fault Zone}

The Pajarito fault zone is a series of north- and northeast-trending en echelon high-angle normal faults that extend from Santa Ana Mesa, around the east side of the mountains, to Abiquiu. North of Santa Clars Canyon, this zone is represented by a series of antithetic faults that merge with faults from the west side of the Jemez. ${ }^{2}$ The Embudo fault strikes northeastward from this point of intersection, ${ }^{33}$ parallel to the Jemez lineament. Slemmons ${ }^{32}$ suggests that the southern end of the Pajarito fault zone may merge with the La Bajada fault system, adding greatly to its length. Near Los Alamos, the Pajarito fault displaces $120 \mathrm{~m}$ of Bandelier Tuff and more than $300 \mathrm{~m}$ of older dacites (Fig. 7). ${ }^{34}$
The faults on the west side of the Jemez Mountains mostly show down-to-the-east displacements and bound blocks that are tilted westward; those on the east are mostly antithetic, bounding eastward-tilting blocks. ${ }^{2}$ These easternmost faults also have greater syn- and post-volcanic displacement, resulting in a pronounced eastward thickening of the volcanic pile. ${ }^{2}$

\section{Jemez Lineament}

The Jemez lineament is an alignment of late Cenozoic volcanic centers that extend from northeastern New Mexico, through the Jemez Mountains, to near Grants, New Mexico (Fig. 1), but may exiend as far west as the Gulf of California.' As the lineament crosses the rift, it offsets the Española and Albuquerque-Belen basins $\mathbf{5 0}$ to $60 \mathrm{~km}$ to the right (Fig. 5) by a series of en echelon northwest- and northeast-trending normal faults. ${ }^{53}$ The zone of intersection includes much of the Española basin. ${ }^{3.33}$ The lineament is probably a transform fault, as suggested by (1) its alignment parallel to northeast-trending Precambrian basement structural trends, (2) opposite dips of basins bordering the lineament, (3) en echelon faulting as it crosses the rift, (4) sharp truncation of the southern ends of the pre-rift Nacimiento and Sangre de Cristo mountains, (5) extensive volcanism along much of its length during the last $5 \mathrm{Myr}$, and (6) a concentrativn of microearthquake activity bordering the lineament. ${ }^{5.7 .1} \cdot 25.33 .35$

Uncommon structural relationships and rock assemblages occur within the zone of intersection of the lineament and the rift. Within this zone lies the 3-km-deep Santo Domingo subbasin. ${ }^{5}$ This small basin is 2 to $3 \mathrm{~km}$ deeper than the adjacent parts of the adjoining basins and is separated from them by steep gravity gradients. ${ }^{5.29}$ The Santa Ana Mesa and Cerros del Rio volcanic fields are located directly over the western and eastern margins, respectively, of the subbasin and volcanic rocks include both tholeiitic and alkali olivine basalts, apparently erupted nearly simultaneously from adjacent vents. ${ }^{5,36,37}$ Geochemical data suggest that basnltic andesites and alkali olivine basalts in the Cerros del Rio are derived from different sources and have followed different evolutionary trends. ${ }^{36}$ The andesitic lavas may have been derived by partial melting in the upper mantle, undergoing crystal fractionation after injection into the crust. ${ }^{37}$ At depths less than about 75 $\mathrm{km}$, a water content in the mantle of $\sim 0.1 \mathrm{wt} \%$ would depress the temperature range over which mantle material melts. ${ }^{5}$ Thus, olivine tholeiite can be derived from 


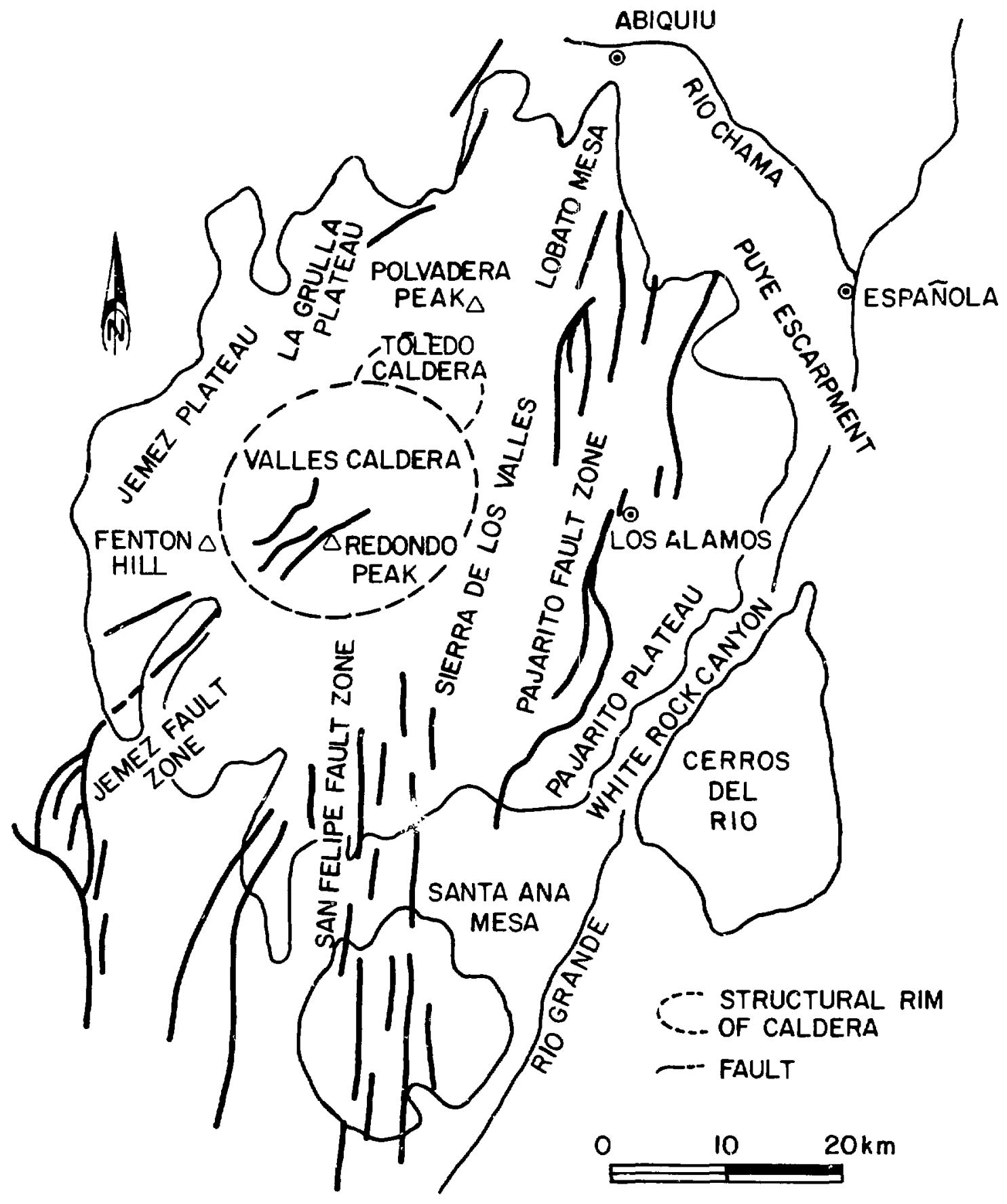

Fig. 6. Generalized map of the Jemez Mountains. 


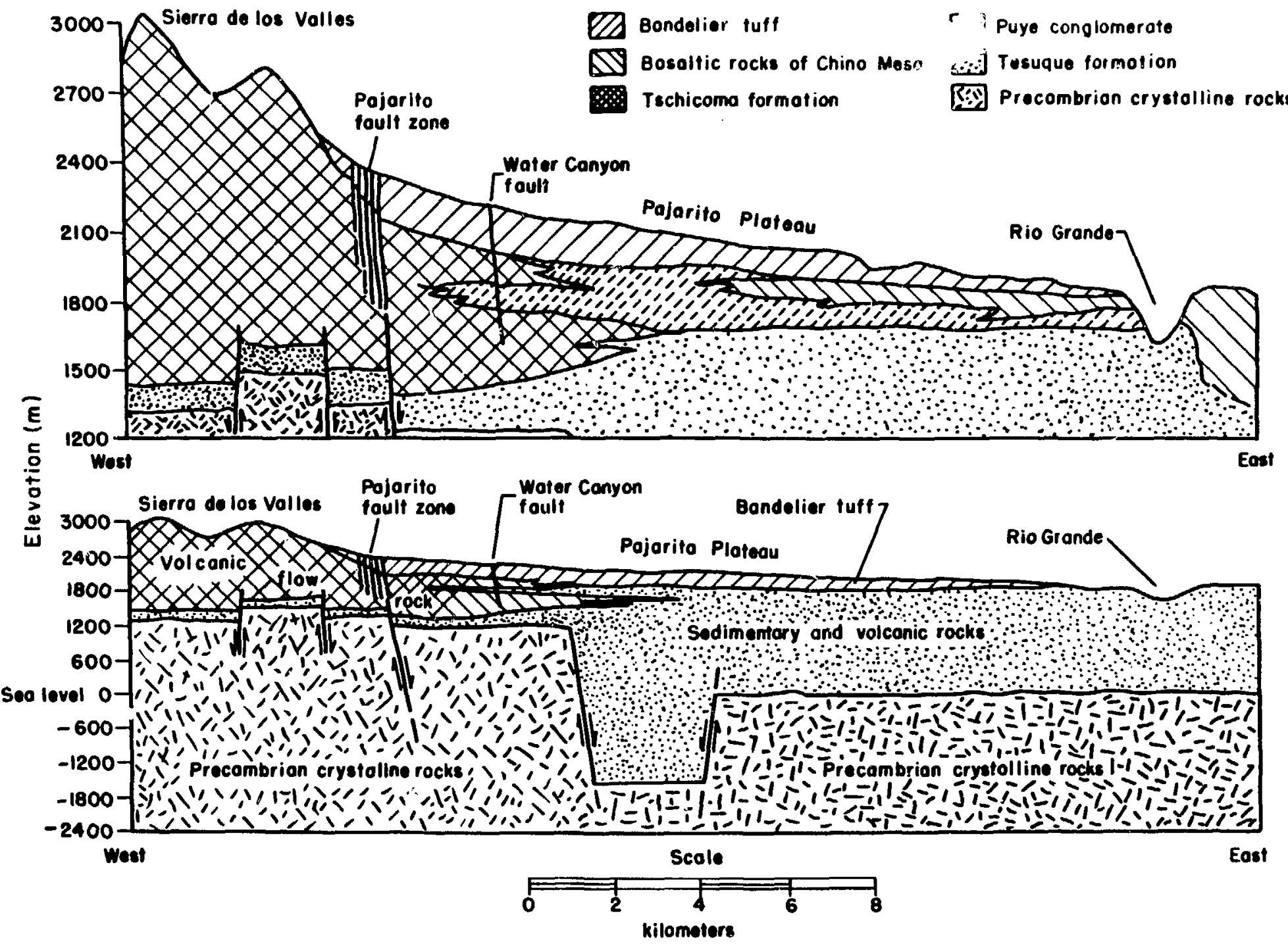

Fig. 7. Geologic stratigraphic relationships of Los Alamos County. 
$>18 \%$ partial melting of spinel pyrolite at a depth of about $35 \mathrm{~km}$, and alkali olivine basalt from about $10 \%$ melting at 50 to $70 \mathrm{~km}$ depth. ${ }^{5}$

One model for the source of these magmas is suggested by geophysical data. Recent seismic refraction studies indicate that crustal thicknesses are $33 \mathrm{~km}$ within the rift, $45 \mathrm{~km}$ in the Colorado Plateau province, and 50 $\mathrm{km}$ in the Great Plains province. ${ }^{38}$ This thinning of the lithosphere suggests the presence of a mantle diapir beneath the rift. Thus, deep fractures along the Jemez lineament are probably capable of tapping magmas at deep levels in the upper mantle, while away from the fractures, within the basins, magmas are drawn from the top of the mantle diapir beneath the rift. ${ }^{5}$ It is not clear that these fractures intersect actual magma. Alternatively, deep fracturing may cause magma production by reducing the confining pressure, allowing solid mantle material to melt. Whatever its mode of production, the magma likely ascends along intersections of rift fractures with the lineament. Many of these magmas rapidly rise to the surface with little compositional alteration, while others collect in shallow crustal reservoirs and undergo extensive crystal fractionation. ${ }^{5}$

\section{Periodicity of Volcanism}

The descriptions of the rocks in the Jemez Mountains presented in Appendix B clearly show several cycles of mafic to silicic volcanism during the last $10 \mathrm{Myr}$. This phenomenon is apparently not unique, but probably occurs in most large volcanic systems. Smith ${ }^{39}$ relates periodicity of volcanism to intermittent thermal inputs (new magma) into the system. The normal compositional trend in a volcanic system is from mafic to silicic. The composition may, however, revert to mafic if the thermal regime does not decline while silicic magma remains in the magma chamber; ${ }^{39}$ a decrease in temperature will eventually lead to crystallization of the magma. Progressive fractionation will result in increasing amounts of silicic magma and at some point in time, the volume of silicic magma may become too large for a complete reversion to a mafic composition to occur. ${ }^{39}$ The magma crystallizes to a granitic pluton and any further additions of mafic material result in the onset of a new cycle. Depending on the tectonic environment, this new cycle may be superimposed on the old one or the location of vents may shift.

This mechanism may explain the apparent cyclic nature of volcanism in the Jemez Mountains. Intermittent injection of mafic magma from the mantle along fractures of the Jemez lineament may feed fractionated shallow crustal magma bodies, resulting in periodic reversions from silicic to mafic lavas erupted to the surface. This pattern is complicated by eruptions of alkali lavas from deep levels of the upper mantle that have not undergone substantial residence time in the crist.

This oversimplified explanation requires considerably more work before it can be verified as an active mechanism in the vicinity of the Jemez Mountains. For example, the effect of changing convective systems caused by periodic injections of fresh magma and the effectiveness of these thermal inputs in remelting hot crystallized or partly crystallized magma are not known. ${ }^{39}$ It does, however, seem plausible in view of the prevailing tectonic environment and the volcanic history of the Jemez Mountains.

\section{GEOLOGIC HISTORY OF THE JEMEZ MOUNTAINS}

The Jemez Mountains are a complex sequence of calc-alkalic to alkali-calcic volcanic rocks surrounded by dissected plateaus and mesas. ${ }^{2,8,40}$ Rocks range fioum basalt, through andesite, dacite, rhyodacite and quartz latite, to rhyolite, ${ }^{2,9,10,41}$ and have a maximum thickness of $1500 \mathrm{~m}^{40}$ Preliminary lead and strontium isotopic data suggest that the mafic rocks are derived from mantle sources and silicic rocks from crustal sources. ${ }^{8}$ During the building of the mountains, active volcanic centers progressively migrated from southwest to northeast. ${ }^{8}$ Locations of individual vents for rocks older than the Bandelier Tuff are probably controlled by primarily north-trending fractures of the rift; vents associated with the tuff are controlled by a nearly circular set of ring fractures. ${ }^{8,40,42}$

By $13 \mathrm{Myr}$ ago the Española basin was a broad shallow trough, bounded by the Nacimiento and Sangre de Cristo mountain ranges. Sediments of the Santa Fe Group were being deposited on top of the Abiquiu Tuff, an older unit that was probably derived from volcanic highlands to the north. A series of faults had developed along the eastern flank of the Nacimientos, a result of tensional stresses active throughout the western United States. Basalts and dacites began to erupt from these fractures in a small zone north of the Jemez area, followed by intrusions of monzonite and diorite dikes and sills. ${ }^{2,26}$ This minor activity was the forerunner of the volcanism that eventually produced the Jemez Mountains. 
Volcanic activity in the present Jemez area began with the eruption of olivine basalts, issuing from many vents scattered over a wide area. ${ }^{2,9,41}$ The basalts did not attain any great thickness, but were fluid enough that, as the eruptions proceeded, the flows overlapped one another, forming a series of low coalescing shield volcanoes with gentle slopes. ${ }^{2}$ At about the same time, local eruptions of rhyolite flows, domes, and tuffs in the southern part of the volcanic field resulted in these being interlayered with the basalt flows. ${ }^{2,9,41}$ Between 9.1 and 8.5 Myr ago, the basalts and rhyolites were followed sequentially by basaltic andesites, andesites, and dacites that built up composite volcanoes on top of the earlier basaltic shields. The composite cones consist of alternating layers of flows and breccias and are intruded by dikes. 2,9,41 Massive flows of dacite, rhyodacite, and quartz latite were also extruded at about this time, attaining a thickness of perhaps $250 \mathrm{~m}$. ${ }^{9,41}$ There followed a period of quiescence, during which the rocks were eroded by stream and wind action. Fresh eruptions in the south-central part of the area produced a sequence of thick rhyolite flows and domes, covering the irregular surface of the older andesites and dacites. ${ }^{9,41}$ Associated air-fall tuffs and glowing avalanche deposits were subsequently reworked locally by streams. ${ }^{2}$ Throughout this early period of volcanism, sediments derived from erosion of the lavas and tuffs were continuously transported away by streams and deposited on the plain immediately south of the volcanoes. These sediments have been subsequently offset by faults of the San Felipe fault zone, so that the formation is a epeated and its full thickness is not exposed. ${ }^{41}$

North of the present calderas, olivine-augite basalt began to flow onto an eroded surface of Santa Fe rocks and Abiquiu Tuff. This succession of many flows forms the present mesas in the northern and northeastern Jemez. ${ }^{41}$ At about this time, the mantle began to rise, uplifting and stretching the overlying crust. ${ }^{4}$ At the top of this regional dome the fractures along the western margin of the basin opened and block faulting began. About 6.7 Myr ago, as doming began, and apparently before the basalt flows had ceased, ${ }^{9}$ fresh eruptions broke out in the central and northern parts of the Jemez area. ${ }^{41}$ The voluminous lavas thus produced form a major part of the interior mass of the present mountains. These rocks consist predominantly of dacites, rhyodacites, and quartz latites, though minor amounts of andesite and rhyolite also occur.,10 By the time these eruptions ceased, about 3.7 Myr ago, this sequence was more than $900 \mathrm{~m}$ thick. ${ }^{9}$ The Velarde graben to the east began to subside, with concomittant formation of the Pajarito fault. Rhyolitic volcanism produced several domes and a small pumice cone north of the central mountain mass. ${ }^{41}$ During the latter part of the period, while the dacitic and latitic eruptions were building up the mountains, the newly-formed ancestral Rio Grande was building up alluvial deposits in the subsiding basin to the east. These sediments consist of river sands containing pebbles and boulders of Precambrian quartzite and granite from uplands to the north. Detritus eroded from the Jemez Mountains was deposited on top of the alluvium as a series of broad fans along the mountain front (Puye Formation). Some lapilli-tuff beds and volcanic mudflows (lahars) are included in this fanglomerate. ${ }^{10,41}$ This sequence is exposed along the Puye Escarpment north and east of the mountain mass.

To the south and southeast of the mountains, olivine-augite basalts, basaltic andesites, and associated pyroclastics erupted along the boundary faults of the Santo Domingo subbasin, building the Cerros del Rio and Santa Ana Mesa volcanic fields. ${ }^{43.44}$ Magma erupting through shallow ground water in these areas caused the water to flash to steam, creating phreatomagmatic explosions that produced maars (volcanic crater not accompanied by lava flows). ${ }^{36}$ Lava flows from the Cerros del Rio periodically dammed the Rio Grande, causing it to change its course, and at least once forming a lake in the basin. ${ }^{26}$

Volcanic activity still continued in the northern part of the mountains. Olivine-augite basalt and cinders were erupted from some of the older vents associated with the 6.7- to 3.7-Myr-old dacites and latites. ${ }^{2.9}$

A period of relative quiescence and erosion in the central part of the mountains was finally broken by two tremendous series of pyroclastic eruptions, separated by $0.3 \mathrm{Myr}$. The first eruptive sequence, 1.4 Myr ago, ${ }^{45}$ deposited about $300 \mathrm{~km}^{3}$ of rhyolite ash and pumice around the central mass. ${ }^{39}$ The roof of the partially emptied magma chamber collapsed, torming the Toledo caldera, $12 \mathrm{~km}$ in diameter (Fig. 6 and cover photo). Rhyolite erupted to the surface as domes, tuffs, and breccias. Intermittent volcanism in the Cerros del Rio continued throughout this period, as basaltic andesite flows overlie these pumice and ash beds in the lower part of White Rock Canyon."

The second eruptive sequence was preceded by a slow redistribution of magmatic constituents, moving dissolved volatiles upward to collect at the top of the magma body beneath the mountains. Increasing magma pressure caused the mountains to expand, with the 
concomitant formation of a 3- to 5 -km-wide circular ring fracture zone $\mathrm{e}^{42}$ at the intersection of the Jemez and San Felipe fault zones. Stretching of the surface of the mountains caused by this regional tumescence may have initiated minor movements along Jemez faults, allowing subsidence of a small block within the fracture zone, forming a graben. ${ }^{42}$ Possible leakage of magma from the fractures may have produced minor eruptions at that time. ${ }^{42}$ Magma pressure continued to increase until, 1.1 Myr ago, $^{+5}$ the eruptions began, possibly resulting from displacements along the fracture zone reducing the confining pressure on the magma. Rapidly expanding volatiles in the magma whipped the polymerized silicate melt to a froth and forced it upward along the ring fractures, resulting in a thin layer of ejected pumice blanketing the flanks of the volcano. Though large caldera-forming eruptions have never been observed, smaller Plinian eruptions from single-vent volcanoes have. ${ }^{46-48}$ Theoretical models suggest that the eruption column above the mountain probably consisted of two parts: a lower gas-thrust zone of pyroclastic material ejected at a high velocity by escaping gas and an upper convective-thrust zone of mostly fine ash and water vapor, rising thousands of meters into the atmosphere by thermal buoyancy. ${ }^{49}$ As eruption conditions changed, possibly caused by a decreasing volatile content or widening of the vent, the gas stream could no longer support the solid material in the gas-thrust zone, which was probably about $4 \mathrm{~km}$ high ${ }^{49}$ but may have reached a theoretical maximum of $9 \mathrm{~km} .^{4,9,50}$ Ash flows resulting from gravitational collapse of the eruption column flowed duwn the flanks of the volcano for a distance of 24 to $33 \mathrm{~km} .{ }^{9,49}$ Although the flows were partially fluidized by hot expanding gases, most of the energy to drive the ash such distances was probably derived from kinetic energy gained during the $4 \mathrm{~km}$ fall. ${ }^{49,50}$

The ash flow eruptions, $300 \mathrm{~km}^{3}$ in volume, ${ }^{39}$ were probably over in less than $10 \mathrm{yr}^{42}$ During the next $10 \mathrm{yr}$, the roof of the magma chamber collapsed along the ring fracture zone, probably as a nearly intact block, accompanied by avalanches and landslides. ${ }^{40,42}$ This nearly circular 20- to 24-km-diameter area, the Valles caldera, truncated the older Toledo caldera (Fig. 6). Following the collapse, rhyolites and tuffs erupted from a northeast-trending zone on the caldera floor. ${ }^{40} \mathrm{~A}$ small amount of quartz latite intruded onto the northeast rim but its relation to other rocks is uncertain. ${ }^{9} \mathrm{~A}$ short period of quiescence followed, during which a lake formed in the caldera. Resurgence of magma began to gradually push thie caldera floor into a steep-sided structural dome, $13 \mathrm{~lm}$ in diameter, which broke into a series of blocks dipping radially as much as $25^{\circ} .{ }^{40}$ The dome, Redondo Peak, has $900 \mathrm{~m}$ of structural and topographic relief. The lake overflowed the caldera. breaching the southwest rim. ${ }^{9.42}$ Additional rhyolites and tuffs issued simultaneously from a graben along the axis of the dome and from the ring fractures on the northwest side of the caldera. ${ }^{40}$ Later eruptions from the fractures produced a nearly complete circle of rhyolite domes insu'e the circumference of the caldera. ${ }^{9}$ The domes were partia" $y$ buried by more lake beds. leaving the tops protruding through the sediments (Figs. 8 and 9). ${ }^{51}$

The latest volcanic activity in the Jemez Mountains occurred more than $42000 \mathrm{yr}$ ago, with the eruption of a series of ash flows, followed by "popcorn" pumice and a small porphyritic obsidian flow near the southwest rim of the Valles caldera. ${ }^{41}$ These last three events indicate a diminishing gas content during the terminal stages of volcanism. ${ }^{2}$ Current geothermal activity is sustained by upward migration of residual heat from the pluton beneath the mountairss. ${ }^{52}$ Subsequent erosion of the Bandelier Tuff has resulted in the formation of narrow finger-like mesas surrounding the mountains. Many of the rock formations are exposed in the Los Alamos area (Figs. 10 and 11). During the last $10 \mathrm{Myr}$, volcanic activity in the Jemez Mountains has been nearly continuous in one part of the mountains or another, and periods of quiescence longer than a few hundred thousand years are unlikely. ${ }^{8}$

\section{GEOPHYSICAL INVESTIGATIONS}

Although much useful information can be gained by studying rocks exposed at the surface, there is a considerable amount of knowledge that cannot be obtained by direct observation. Data regarding conditions in the subsurface are collected by a variety of geophysical methods, such as seismic, gravity, and electrical surveys, and identification and investigation of thermal anomalies. Geophysical studies in the Rio Grande rift and the Jemez Mountains are invaluable tools, aiding in the interpretation of surface observations and in model development.

\section{A. Regional Seismicity}

A knowledge of seismic activity in the vicinity of the Jemez Mountains can be a useful tool to detect possible movements of magma in the crust. Seismic monitoring of volcanoes is a common method in eruption prediction. 


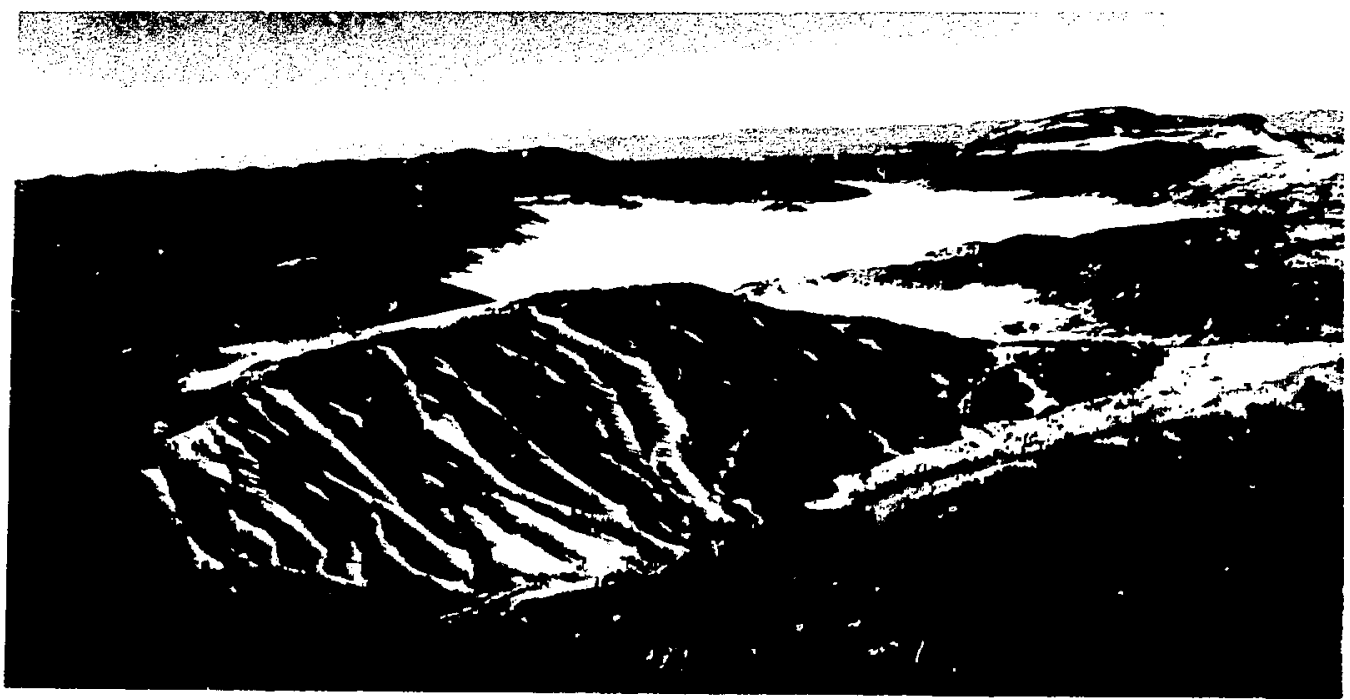

Fig. 8. Valle Grande looking southwest across Pajarito Mountain. South Mountain is in the center background. The high peak at top right is Redondo Peak.

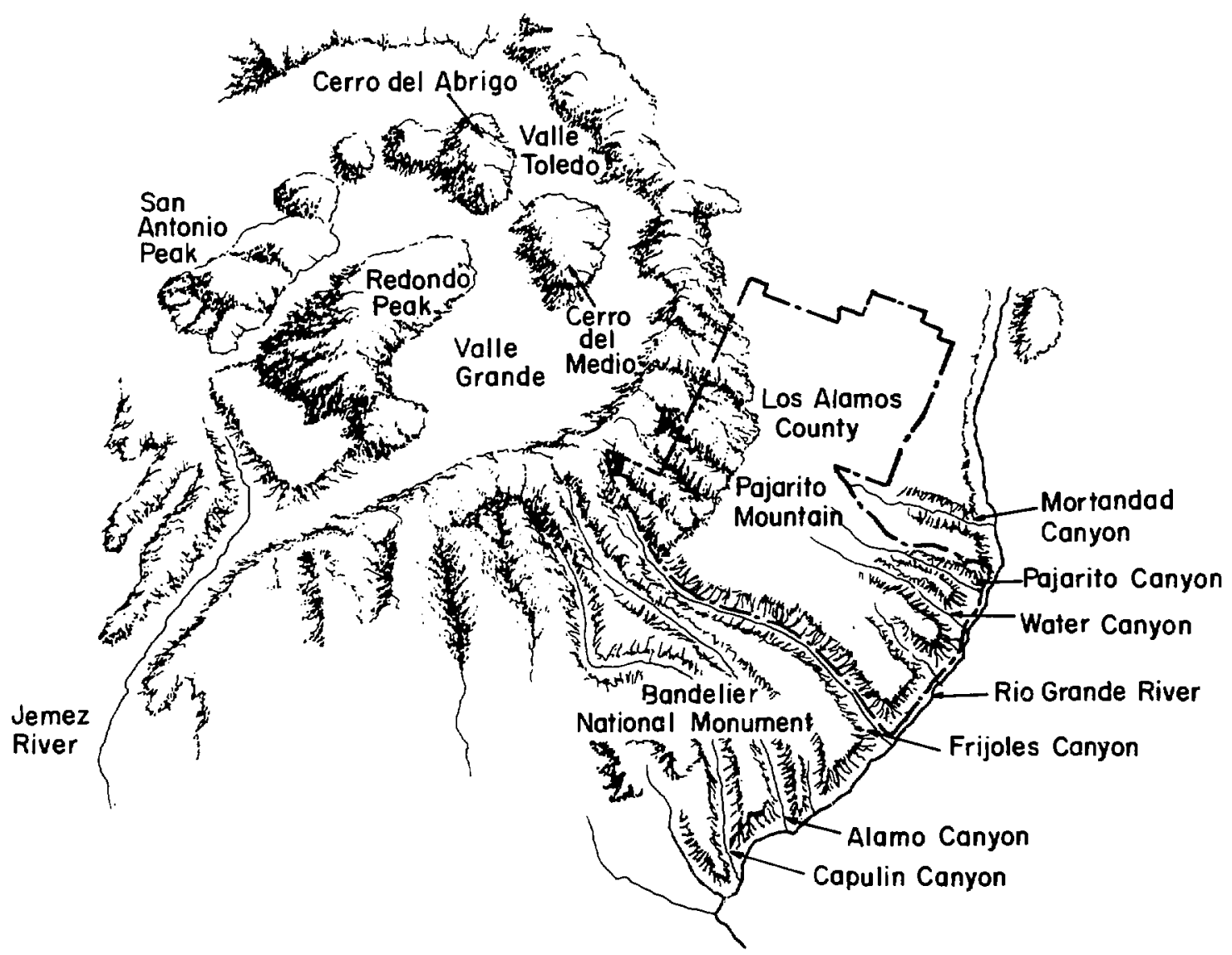

Fig. 9. Relief map of the Valles and Toledo calderas and part of the Pajarito Plateau. The nearly circular ring of domes is aligned on part of the ring fracture zone that bounds the Valles caldera. 


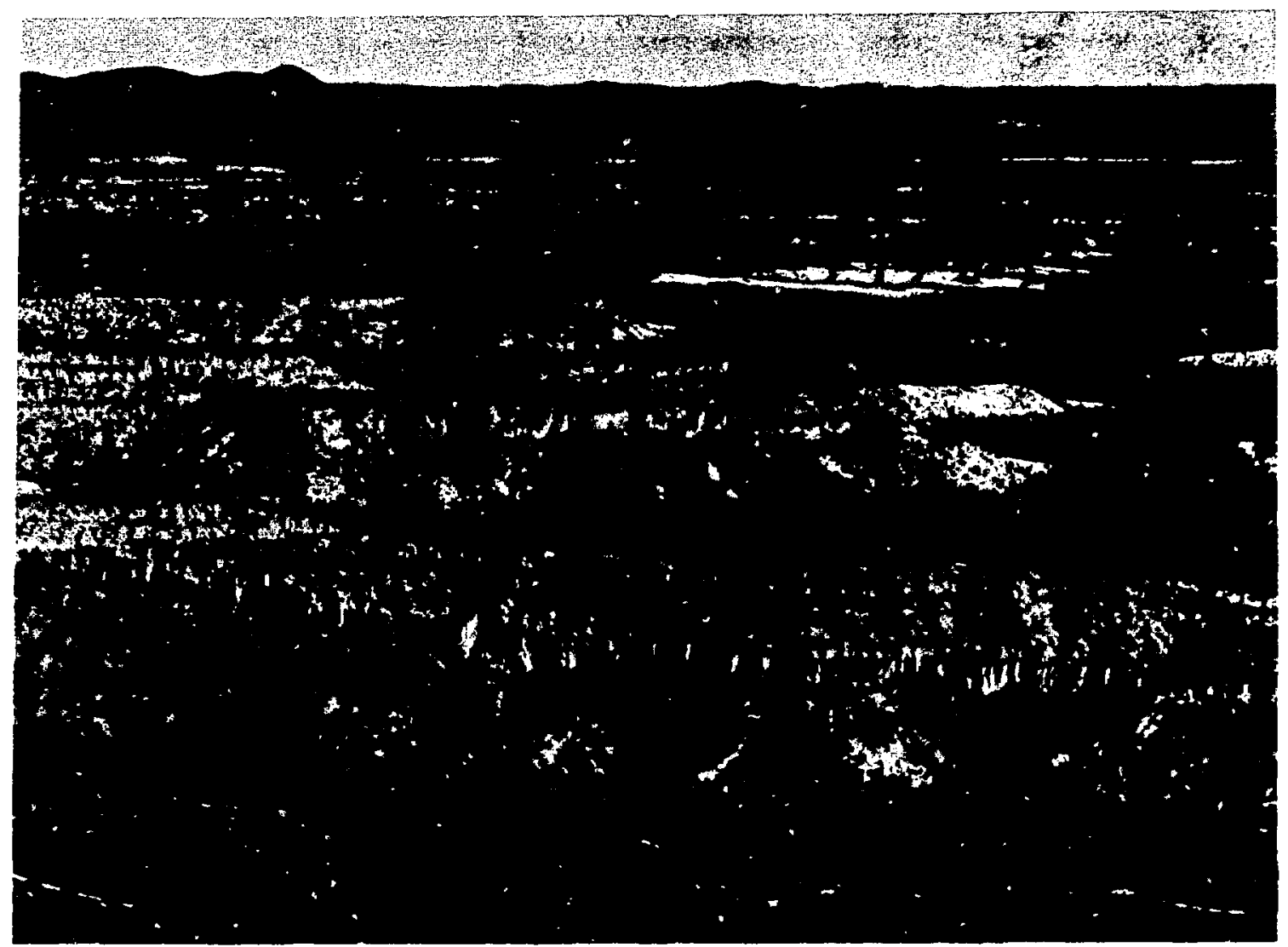

Fig. 10. Part of the Pajarito Plateau northeast of Los Alamos. The narrow mesas are composed entirely of Bandelier Tuff. The 1.1-Myr-old Tshirege Member, associated with the Valles caldera, forms the steep cliffs. The alternating vertical cliffs and steep slopes in the Tshirege are caused by differential welding of the ash flows, resulting in units of variable hardness. The Tshirege unconformably overlies the softer 1.4-Myr-old Otowi Member, which is genetically related to the Toledo caldera. The Otowi is seen as white patches cropping out beneath the talus slopes below the cliffs and as spurs leading out from the second and third mesas. Canyons as deep as $45 \mathrm{~m}$ were cut in the Otowi before deposition of the Tshirege. Pueblo Canyon is in the foreground. The treeless patch in the lower right is a prehistoric Indian ruin.

Magmas ascending to the surface may cause tremors and, before an eruption, there is usually an increase in the number and magnitude of earthquakes at shallow depths. ${ }^{53}$ A carefully designed seismograph netw'ork can sometimes predict the point of eruption several days to several weeks beforehand. Such a monitoring network provided 6 months' notice of the December 1959 eruption of Kilauea, Hawaii. ${ }^{53}$ The first 1980 eruption of Mount St. Helens, Oregon, was preceded by increasing seismic activity. The first earthquake, of magnitude 4.1 (Richter magnitude), was recorded on March 20. Activity increased steadily until, by March 24, the tremors, mostly between magnitudes 3 and 4, were occurring so rapidly that they overlapped. ${ }^{54}$ Following the first volcanic explosion on March 27, the magnitude of earth- quakes began to increase, eventually reaching magnitude $5 .^{54}$ Harmonic tremors, indicating magma movement at shallow levels, began on April 3, and the main eruption took place on May $18 .^{54}$ In the Jemez Mountains, long-term seismic monitoring provides a baseline to which any significant deviation can be compared, and perhaps adequate warning of magmatic activity at depth can be obtained.

A more important application of such a monitoring network, however, is that seismic data can provide an indication of the intensity of rifting processes. As has been discussed earlier, continuing volcanism in the Jemez Mountains may be associated with periodic injections of new magma, rising along the intersections of rift fractures with the Jemez lineament. Active spreading in the 


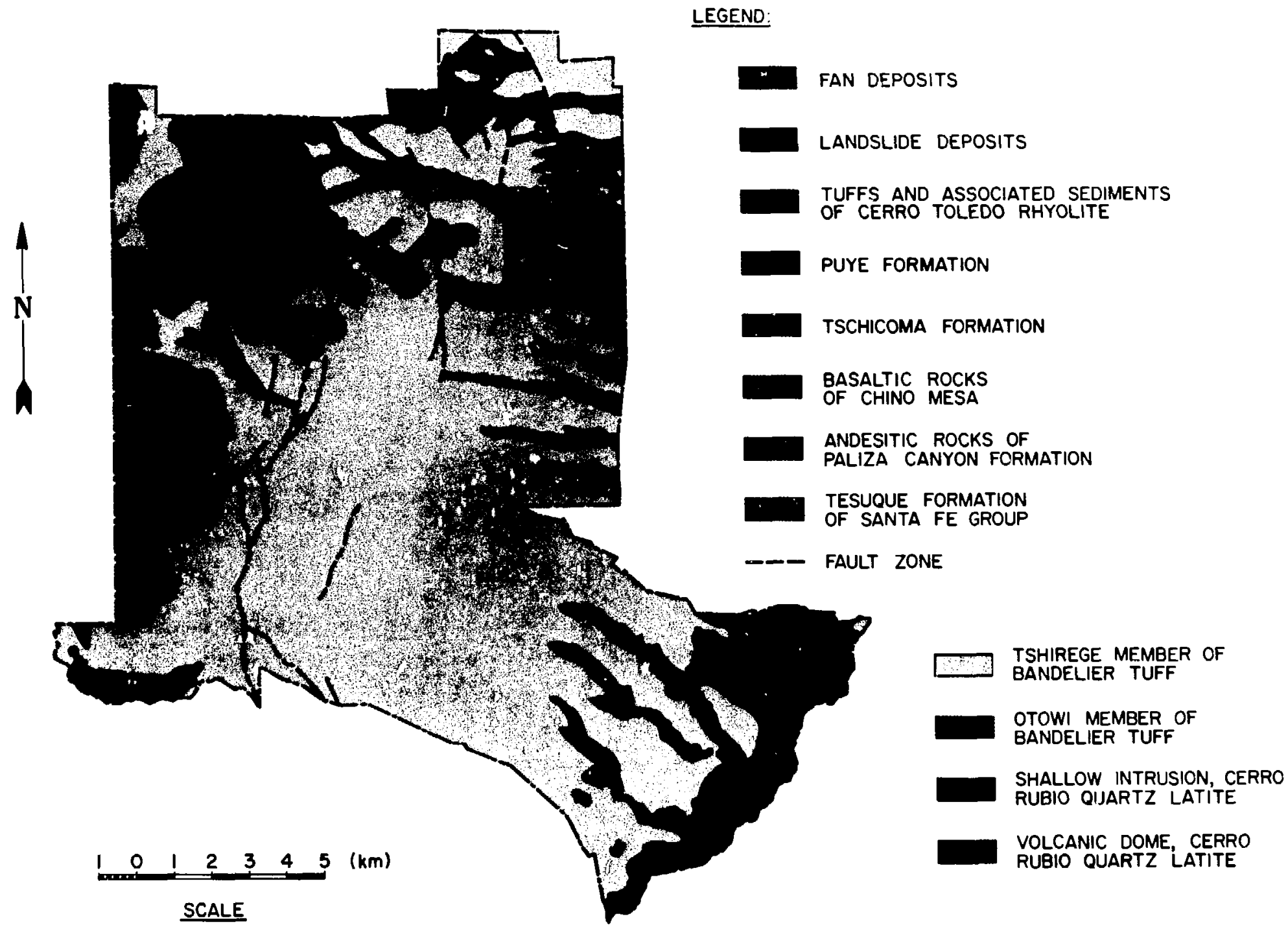

Fig. 11. Genlogic map of Los Alamos County showing exposures of Miocene to Holocene volcanic and sedimentary rocks. 
rift may facilitate the movement of magma to shallow levels. Thus, in a long-term sense, volcanism in the vicinity of the Jemez Mountains may be related to the intensity of rifting.

The largest percentage of earthquakes in the Jemez region is along the Jemez lineament, ${ }^{5 s}$ occurring as a band of noderate seismic events between Grants and the southern end of the Nacimiento Mountains (Fig. 1). ${ }^{35}$ The most consistently active microearthquake area is in a 50-km-long north-trending zone on the northeast side of the Jemez Mountains, between Abiquiu and Española, along an extrapolation of the Pajarito fault (Fig. 6). 2.35,55 Ten kilometers to the east is a $19-\mathrm{km}$-wide area that underwent $49 \mathrm{~mm}$ of relative subsidence between 1934 and 1939 , as indicated by geodetic releveling data. ${ }^{36} \mathrm{Just}$ to the west of the seismic zone is a late Tertiary dike swarm. Dikes are common on the uplifted borders of the rift, but this is the only such concentration within the rift. ${ }^{31,56}$ Reilinger et al..$^{36}$ concluded that the subsidence is consistent with deflation of a magma body at about 10 $\mathrm{km}$ depth, and hypothesize that the seismic activity may be associated with magma injection into fracture systems. This area is at the western edge of the Velarde graben and, alternatively, the microearthquakes may be related to dislocations along the graben's boundary faults. ${ }^{35.56}$ Arguments in favor of the magma hypothesis are (1) a heat flow measurement of $220 \mathrm{~mW} / \mathrm{m}^{2} 30 \mathrm{~km}$ to the northeast, ${ }^{57}$ suggesting unusually high thermal activity in that part of the basin, (2) a crustal buige near Socorro that has been associated with a shallow magma body, and (3) a second crustal bulge of uncertain origin east of El Paso. ${ }^{36}$ The mechanism controlling the activity is probably the same for the Española and Socorro features, though resulting in opposite surface effects. ${ }^{35,36}$

Most of the seismic activity in the region is limited to depths less than about $20 \mathrm{~km} .^{1,3}$ Seismic refraction profiles from surveys in the rift indicate the presence of a discontinuity at about $21 \mathrm{~km}$, where P-wave velocities change from $6.0 \mathrm{~km} / \mathrm{s}$ above to $6.4 \mathrm{~km} / \mathrm{s}$ below. ${ }^{38}$ These data suggest that one or more layers in the lower crust have low rigidity and would generate fewer earthquakes. ${ }^{35,38}$ There is little correlation between mapped epicenters and known surface faults, perhaps because of uncertainties in epicenter locations for microearthquakes. ${ }^{35}$ The range of focal depths is consistent with those in other parts of the state. ${ }^{1}$ Sanford et al..$^{35}$ have commented that the low number and spatial distribution of earthquakes in the rift suggest that rifting may be in abeyance at the present time.
An important characteristic of the Jemez region is the near-aseismicity within a circle of radius $30 \mathrm{~km}$ centered on the north rim of the Valles caldera. ${ }^{1,35,55}$ The area is well covered to a very low detection threshold, so the anomaly is not the result of inadequate monitoring. A similar aseismic area is located in the northern part of the Albuquerque-Belen basin. Both of these areas, bordering the Jemez lineament, are regions of high heat flow and it has been suggested that tectonic strain is being released by plastic deformation of the rocks rather than brittle fracture. ${ }^{1,35,36}$

\section{B. Other Geophysical Studies}

A comprehensive data base from which to calculate reasonable probability estimates for future volcanism in the Jemez Mountains is not complete without a review of the regional thermal regime. The intensity and spatial distribution of heat sources yield interesting implications for continued magmatic activity. When these are added to the preceding discussions, a fairly plausible, if crude, picture emerges.

Tectonic provinces have long been recognized as areas of greater than average terrestrial heat flow. ${ }^{51}$ Heat flow is asually calculated as the product of the measured thermal gradient in well holes and the average thermal conductivity of the rocks encountered. Average worldwide heat flow values are about $50 \mathrm{~mW} / \mathrm{m}^{2} .{ }^{58}$ There are only two areas in the southern Rocky Mountain Province that exhibit heat flows greater than $105 \mathrm{~mW} / \mathrm{m}^{2}$ : the San Juan volcanic field in southern Colorado and the Rio Grande rift (Fig. 1). Regionally averaged heat flows along the rift are $107 \pm 27 \mathrm{~mW} / \mathrm{m}^{2}$, excluding values above $170 \mathrm{~mW} / \mathrm{m}^{2}$, and suggest partial melting at depths of 15 to $55 \mathrm{~km}$; analysis of the half-width of the heat flow anomaly suggests the presence of a heat source at 20 to $30 \mathrm{~km} .{ }^{59}$ Measurements along the west side of the Jemez Mountains are between 84 and $190 \mathrm{~mW} / \mathrm{m}^{2}$ and heat flows within the Valles caldera range from 130 to $210 \mathrm{~mW} / \mathrm{m}^{2} .{ }^{59,35}$ These areas lie within a band of high flow that parallels the Jemez lineament from the western part of the Albuquerque-Belen basi . , through the Jemez Mountains, to Trinidad; Colorado. Heat flows greater than $420 \mathrm{~mW} / \mathrm{m}^{2}$ have been recorded only in the Rio Grande rift south of the Española basin. ${ }^{59}$

A recent magnetotelluric survey in the Valles caldera has shown that, though there is a significant concentration of crustal hydrothermal activity, it is localized and controlled more by shallow structure than by a regional 
convective system associated with an active magma body. ${ }^{32}$ Thus, the caldera is apparently underlain by a cooling granitic pluton, and the present hydrothermal activity is the result of residual heat leaking upward along fractures in the subsided caldera block. The pluton is probably steep-sided ${ }^{31}$ with an area about the same size as the caldera itself, because the magma is assumed to have followed the ring fracture system during its ascent.

Though magma does not occur at shallow depths, the magnetotelluric data suggest the presence of a zone of accumulation at about $15 \mathrm{~km}$ depth, inferred to be tholeitic in composition..$^{52}$ An earlier study had identified a similar magma body beneath Santa $\mathrm{Fe}$ at the same depth. ${ }^{23}$ Limits to this body are from $750 \mathrm{~m}$ thick at $100 \%$ melt to $6 \mathrm{~km}$ thick at $15 \%$ melt. ${ }^{23.52}$ These magma bodies may be the same and, if so, are probably contiguous with similar magmas beneath Socorro (18 to $23 \mathrm{~km}$ depth) and El Paso (27 km depth). ${ }^{23,52}$ The present hydrothermal activity in the Valles caldera is related to residual heat from more intense activity over the last several million years. ${ }^{32}$

As part of the Laboratory's Hot Dry Rock Geothermal Energy Developr.1ent Program, three test holes were drilled at Fenton Hill, on the Jemez Plateau (Fig. 6) near the west rim of the Valles caldera. Geothermal gradients measured in these holes are 50 to $60^{\circ} \mathrm{C} / \mathrm{km},{ }^{27}$ considerably higher than the global average of $30^{\circ} \mathrm{C} / \mathrm{km}$. Apparent potassium-argon age dates were obtained on samples taken from above and below the $2.17 \mathrm{~km}$ depth. A comparison of the two sample sets indicates that the deeper samples have not lost more argon, though the temperature at $3 \mathrm{~km}$ exceeds $200^{\circ} \mathrm{C}$, suggesting that the present geothermal gradient is the highest achieved in the last $1370 \mathrm{Myr}^{27,60}$ This implies that the temperature at the site is still rising since the caldera-forming eruptions. ${ }^{27}$ Because the site is near the ring fracture zone that bounds the caldera, the high observed temperature may record residual heat rising along these fractures.

Another area of possible geothermal potential lies beneath the city of Los Alamos. A recent time domain electromagnetic sounding survey identified a northeast-trending trough in excess of $3000 \mathrm{~m}$ deep beneath the city. ${ }^{61}$ The trough, which apparently ends south of Los Alamos and shallows to the northeast, may be a closed basin. Resistivity data suggest that interstitial fluid in the rock is affected by either salinity or elevated temperature. Because geoelectric layers identified by this kind of survey may not coincide with the actual rock layers, the relation of the crough to the Velarde graben is uncertain.

Seismic activity in the vicinity of the Jemez Mountains is relatively low and characterized by generally shallow focal depths. The spatial association of an active microearthquake area with a zone of recent subsidence northeast of the mountains suggests that magma may be moving in the shallow crust. Other geophysical data suggest that a thin magma body may underlie much of this part of the rift, though there is no evidence that the high-level magma chamber associated with the most recent volcanism in the Jemez Mountains is still active. Although the mountains lie within a zone of high heat flow, current geothermal activity in and near the Valles caldera seems to be related to residual heat rather than to active magmatism.

\section{VOLCANIC EVOLUTION OF THE JEMEZ MOUNTAINS}

The preceding sections have reviewed, ir. a general way, most of the published information related to volcanism in the Jemez region. This section attempts to synthesize that information inio a very crude speculative "model" of the processes that have led to the modern Jemez Mountains.

It was mentioned earlier that seismic evidence suggests that the rift may not be spreading at the present time. This does not, however, imply that rifting has terminated once and for all. The rift, like any spreading center, is characterized by intermittent activity, with alternating periods of activity and quiescence. The length of these respective periods is governed by the large-scale plate tectonic forces that initiated rifting in the first place, and these forces are not as well understood as we would like. There are many rift zones in the world that have apparently ceased spreading in various stages of their development, but there is no evidence to suggest that the Rio Grande rift is one of them.

Deep fractures of the Jemez lineament, whether it is a transform fault or not, are probably capable of tapping magmas at great depth. In the tensional environment of the rift, intersections of fractures associated with the rift and the lineament would facilitate upward migration of these magmas. Some erupt to the surface soon after injection into the crust and some collect in shallow crustal reservoirs, where they undergo extensive crystal fractionation. The validity of this suggestion is supported by the complex petrology of rocks in the Cerros del Rio and geophysical evidence for a thin layer of magma 
beneath this part of the rift. While in residence in the crust, redistribution of magmatic constituents results in progressive zonation of the magma body, with the silicic fraction concentrating at the top. The degree of fractionation depends on the residence time and the intensity of the thermal regime.

The normal compositional trend of volcanism, from mafic to silicic, may be influenced by periodic thermal inputs, perhaps during periods of active rifting. These intermittent injections of new magma into the Jemez volcanic system may explain the apparent cyclic nature of volcanism in the mountains. The concurrent basaltic and rhyolitic volcanism during the early history of the mountains and the eruptions of mafic lavas just preceding, and contemporary with, the first caldera-forming eruptions may also be related to this mechanism.

A region of exceptionally low seismicity surrounding the Valles caldera suggests that the magma body that produced the Bandelier Tuff and Valles Rhyolite is not yet completely crystallized to a rigid body. A hot, partially crystallized mass would deform plastically under stress, giving rise to fewer earthquakes than would a cooled granitic rock. The perhaps still-rising temperature inferred from rock samples taken at depth at the Fenton Hill site and localized thermal activity associated with the boundaries of intracaldera structures also indicate that the pluton is still cooling. The absence of a regional convection system beneath the Valles caldera and the lack of mafic volcanism in the last million years (and, hence, possibly insufficient new thermal inputs) suggests that the pluton may be cooling rather than heating. If this is the case, then major future volcanism would be unlikely until new thermal inputs are added to the system. A thin layer of magma at about $15 \mathrm{~km}$ depth beneath this part of the rift may be residual or the result of slow leakage along deep fractures. At the present time it is impossible to determine which alternative is more likely.

Although there may be magma moving in the crust just northeast of the mountains, the mafic dikes that are at least spatially related to the activity have been dated as late Tertiary and, therefore, pre-date the calderaforming eruptions. This does not, however, preclude the possibility that active dike injection is occurring at depth. Much more work is needed before this question can be resolved.

\section{VI!. FUTURE VOLCANISM IN THE JEMEZ MOUNTAINS}

Radioactive wastes at Los Alamos are disposed of in several shallow land disposal facilities at widely scattered locations on the Pajarito Plateau (Fig. 3). Because of the long time period over which radioactive wastes remain hazardous, long term integrity of these sites must be ensured. Toward this end, it is important to evaluate the potential for continued volcanic activity in the Los Alamos area, as volcanic eruptions can be an effective mechanism in releasing radionuclides to the environment. Estimates of potential volcanic activity have been reported for other regions. ${ }^{62-64}$

It is highly likely that surface volcanism in the vicinity of the Jemez Mountains will continue in the future. In the absence of data to suggest an increase in magma production rates, we must assume the continued eruptive activity will proceed at about the same rate as in the past. The rate of volcanism in the Jemez Mountains during the last $10 \mathrm{Myr}$ has been about $5 \times 10^{-9} / \mathrm{km}^{2} / \mathrm{yr}$. Volcanic events have occurred during discrete periods, alternating with periods of relative quiescence that probably lasted up to a few hundred thousand years.

Lava flows or ash flow sheets originating at a distance of greater than a few kilometers and flowing over a disposal site would probably have little potential to release waste radionuclides because all the sites at Los Alamos are located on top of the nearly flat mesas. Lava flowing over a gentle slope would not be particularly erosive, and even ash flows or pyroclastic surges moving at a typically high velocity would not be capable of scouring to any significant depth below grade. If the pit caps were especially thin, heat from a flow may volatilize a small portion of the radionuclides (notably tritium), which could then percolate upward through the flow as a gas. The waste pits are capped with 1 to $3 \mathrm{~m}$ of crushed tuff and stabilized by revegetation. ${ }^{11,16}$ Chronic erosion, however, could reduce the thickness of the cover over a long time period. Estimated rates of vertical erosion on the mesas are about $22 \mathrm{~mm} / 1000 \mathrm{yr},{ }^{12.13 .16}$ so it should take about $45000 \mathrm{yr}$ for natural processes to excavate to a depth of $1 \mathrm{~m}$. By that time, most of the radionuclides (except long-lived transuranic elements) will have decayed to very low levels. The major effect of flows covering the site would be to merely increase the pit cover by an amount equal to the thickness of the flow. 
The only plausible mechanism by which an eruption could have a significant effect would be if a volcano should erupt very near to a site, physically disrupting t. For this case, we must consider the area of intersection of a volcano with a disposal site. This relationship is shown in Fig. 12. The dimension $r_{1}$ is the radius of the area affected by the volcano and $r_{2}$ is the radius of the disposal site, assumed to be circular. If the core of the volcano intrudes anywhere within an area of radius $r_{3}=$ $r_{1}+r_{2}$, then the site will be disrupted. The disposal sites at Los Alamos are all of different sizes, resulting in a different value of $r_{3}$ for each. Therefore, the probability of any disposal site being directly affected is the summation of the individual probabilities of a volcano occurring within a unique radius $r_{3}$ of each site:

$$
p=\sum_{i=1}^{n} P_{1},
$$

where $\mathrm{p}$ and $\mathrm{P}$ are the total and individual probability, respectively, of site disruption and $n$ is the number of sites. Smith ${ }^{65}$ reports that the average core height $h$ of a new land-sited volcano is $430 \mathrm{~m}$ and the diameter of the affected area is $5 \mathrm{~h}=2150 \mathrm{~m}$. Thus, the probability of $\mathrm{a}$ volcano affecting any Laboratory disposal site is about $2 \times 10^{-7} / \mathrm{yr}$.

The actual approach used by Smith, however, was a bit more general. He estimated that an average of one new volcano has appeared every $20 \mathrm{yr}$ during the last 225 yr. A uming a circular disposal site, his equation for the pr uoability $\mathrm{p}_{\mathrm{v}}$ of a new volcano affecting at least part of the site is

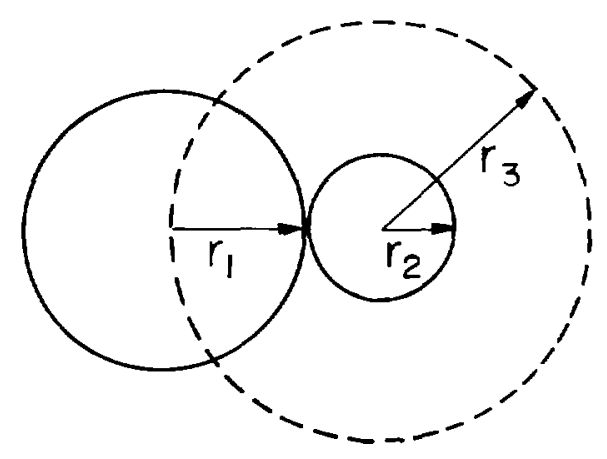

Fig. 12. Diagram showing the area affected by a volcano intruding close to a circular disposal site. See text for explanation.

$$
p_{v}=\frac{\pi\left(R_{F}+5 / 2 h\right)^{2}}{20 \pi d^{2}}
$$

where $R_{F}$ is the radius of the site and $d$ is the diameter of the earth. About $98 \%$ of the volcanoes on earth are spatially related to convergent plate boundaries (trenches), the remaining $2 \%$ being associated with divergent plate boundaries (spreading ridges and rift zones). ${ }^{66}$ By this equation, the probability of a new volcano affecting any Laboratory disposal site is about $8 \times 10^{-11} / \mathrm{yr}$, more than three orders of magnitude less. This difference suggests that caution must be used when performing calculations of this kind. Geologic systems have not always performed as predicted. ${ }^{67-69}$

Probability estimates are based on an average rate through time of an occurrence, derived from empirical data, and can be extrapolated into the future only under certain conditions. First, we must assume that the factors controlling the observed phenomena will not change, or at least change in a predictable way. Second, we must remember that a probability estimate is not a prediction for the future, but merely a statement of past occurrence rates. The time period over which future extrapolation of an estimate remains 'alid depends on the quality of the data base and the nature of the phenomenon. The data used must be as specific as possible, as evidenced by two different estimates for the same occurrence noted above. For ręular cyclic phenomena, observation of a few cycles is generally sufficient to define the cycle, and the estimate should remain valid until the factors controlling the cycle change. For non-cyclic phenomena, such as volcanism, observations must account for a much longer period of time, reducing the short term accuracy of the estimate.

\section{CONCLUSIONS}

The Rio Grande rift evolved along old crustal flaws in the southern Rocky Mountains as a result of large scale plate tectonic forces that have been active throughout the western United States during 'he last 30 Myr. Strong regional uplift, with block faulting and voluminous bimodal volcanism, was probably caused by mantle upwelling after $13 \mathrm{Myr}$ ago. In northcentral New Mexico, the rift is a north-northeast-trending succes sion of en echelon basins that are offset by transverse structures (lineaments).

The Jemez Mountains lie astride the downfaulted western margin of the Española basin, where the rift is 
crossed by the Jemez lineament, which occurs as a northeast-trending alignment of late Cenozoic volcanic centers. Volcanism along the lineament has been especially active during the last $5 \mathrm{Myr}$. Deep fractures of the lineament are probably capable of tapping deep magmas within the mantle, which move upward along the intersections of rift fractures with the lineament. Some of these magmas erupt to the surface and some collect in shallow crustal reservoirs, where thoy undergo extensive crystal fractionation. The cyclic r gture of volcanism in the Jemez Mountains may be caused by intermittent injections of new magma into the Jemez volcanic system, perhaps during periods of active rifting. Seismic evidence suggests that the rift may not be spreading at the present time.

The vicinity of the Jemez Mountains is characterized by relatively low seismic activity, with generally shallow focal deptins. The spatial association of an active microearthquake area with a zone of recent subsidence northwest of the mountains suggests that magma may be moving in the shallow crust. Other geophysical data suggest the presence of a thin layer of magma beneath inis portion of the rift, though there is no evidence that the high level magma body associated with the most recent volcanism in the Jemez Mountains is still active. Although the mountains lie in a zone of high heat flow, current geothermal activity in and near the Valles caldera is probably related to residual heat rising along fractures and shallow structures rather than to active magmatism. The magma body that produced the Bandelier Tuff is apparently a cooling granitic pluton.

The rate of volcanic activity in the Jemez Mountains during the last $10 \mathrm{Myr}$ has been about $5 \times 10^{-9} / \mathrm{km}^{2} / \mathrm{yr}$ and is characterized by periods of active volcanism alternating with periods of relative quiescence up to perhaps a few hundred thousand years in length. Lava or ash flows originating at a distance and uverriding a disposal site would have little potential to release radioactivity to the environment, but a new volcano intruding close to a site may be an effective release mechanism. The probability of a new volcano disrupting a Laboratory radioactive waste disposal site is about $2 \times 10^{-7} / \mathrm{yr}$.

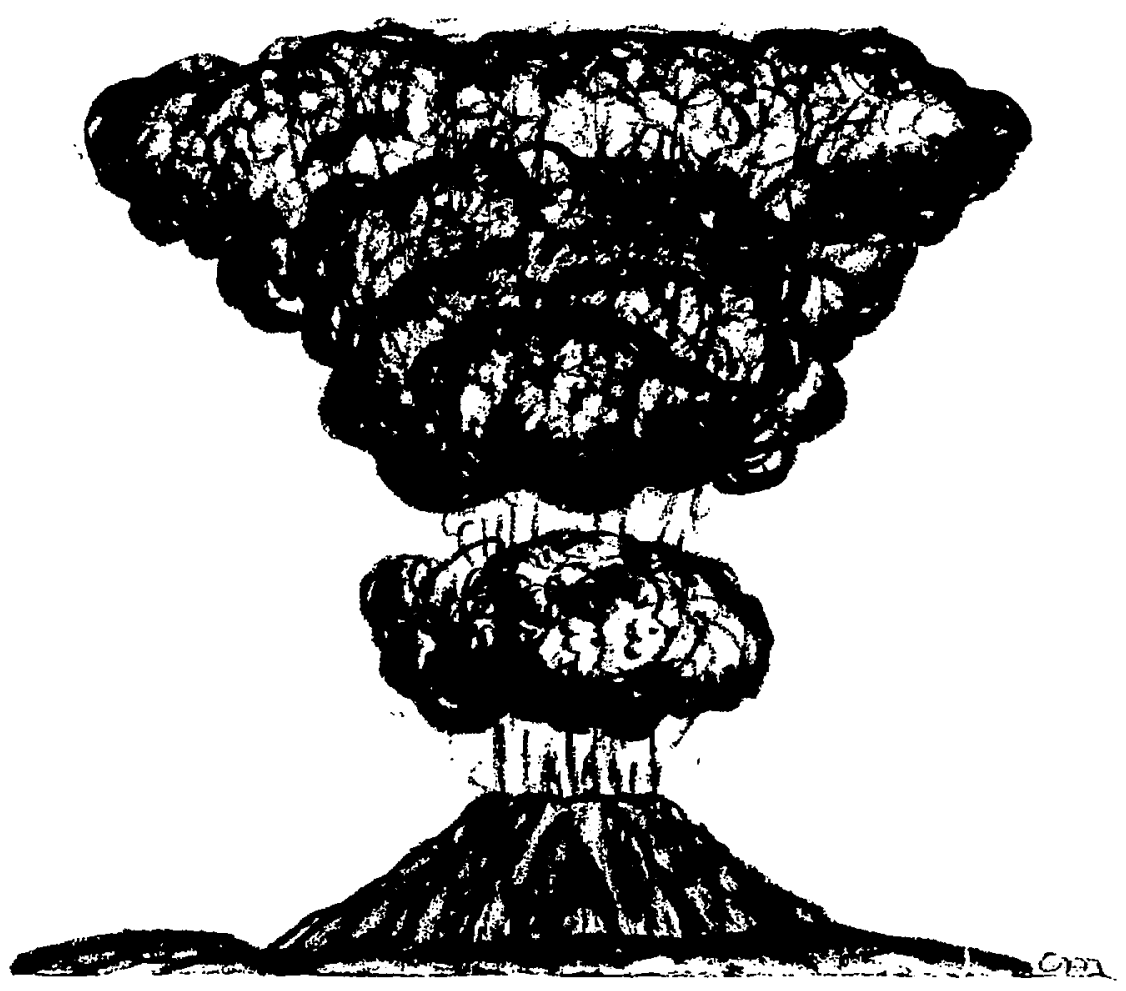


APPENDIX A

GEOLOGIC TIME SCALE

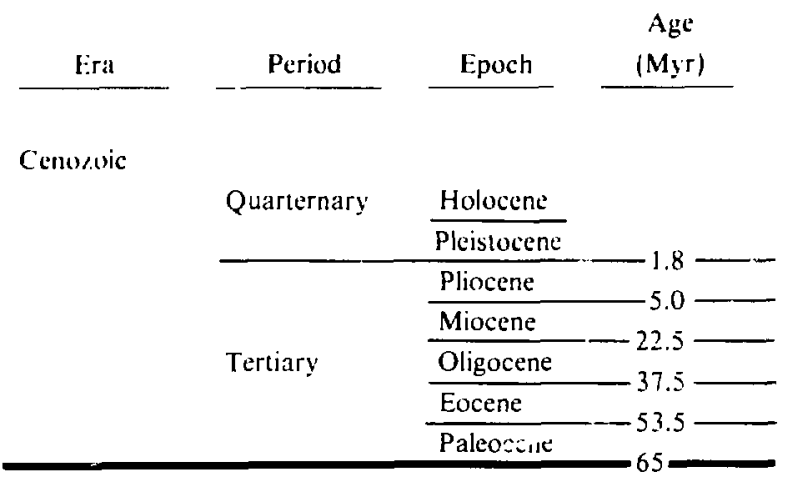

Mesolvic

Cretaceous

\begin{tabular}{ll}
\hline Jurassic & $136-190-195-$ \\
\hline Triassic & -225
\end{tabular}

Paleozoic

\begin{tabular}{ll} 
Permian & $280-320-34-35-430-440-$ \\
\hline Pennsylianian & Mississippian \\
\hline Devonian & $500-$ \\
\hline Silurian & Ordovician \\
\hline Cambrian
\end{tabular}

Precambrian

${ }^{8}$ Sources: Geological Society of London ${ }^{70}$ and Berggren ${ }^{71}$ 


\section{APPENDIX B \\ ROCKS OF THE JEMEZ MOUNTAINS}

\section{KERES GROUP ${ }^{3}$}

Rocks of the Keres Group are the oldest volcanics erupted from vents within the area of the present Jemez Mountains. This group consists of basaltic, andesitic, dacit' ${ }^{\prime}$, and rhyolitic rocks oltcropping in the southern part of the mountains and a.e late Miocene in age. The total maximum thickness probably exceeds $1800 \mathrm{~m}$ but no more than about $900 \mathrm{~m}$ are exposed.

\section{A. Basalt of Chamisa Mesa ${ }^{9,41}$}

The oldest rocks of the Jemez Mountains are the basalts of Chamisa Mesa. The formation consists of a thin sequence of olivine basalt flows and has a maximum thickntss of abotit $4: \mathrm{m}$.

\section{B. Canovas Can:on Rhyolite 9.41}

The Canovas Canyon Rhyolite, named for exposures in Canovas Canyon, is a series of rhyolite flows, bedded tuffs, massive pumice breccias, domes, and shallow intrusions. The formation has a maximum thickness of $270 \mathrm{~m}$ in the Bear Springs area, thinning to less than 30 $\mathrm{m}$ beneath Borrego Mesa. Phenocrysts of biotite, sanidine, and quartz are often present. Source vents have been identified at Bear Springs Peak and Borrego Doms. The age of the formatior is late Miocene.

\section{Paliza Canyon Formation ${ }^{9,41}$}

The Paliza Canyon Formation, named for exposures in Paliza Canyon, consists primarily of hypersthene-augite andesite and some olivine-bearing basaltic andesite occurring as flows, flow breccias, tuff breccias, and dikes. These rocks, erupted from many coalescing composite volcanoes, are lenticular in nature and generally grade upward from basaltic andesite, through andesite, to dacite. The fnrmation also includes up to $250 \mathrm{~m}$ of massive flows of porphyritic dacite, rhyodacite, and quartz latite containing phenocrysts of pyroxene, iornblende, biotite, and quartz. Maximum thickness is probably about $900 \mathrm{~m}$, though only about $460 \mathrm{~m}$ are exposed. Dacite. of the Paliza Canyon Formation have been dated by $\mathrm{K}$-Ar methods as 8.5 to $9.1 \mathrm{Myr}$ old.

\section{Bearhead Rhyolite $e^{9,41}$}

The Bearhead Rhyolite, named for one of its major source vents on Bearhead Peak, consists of thick rhyolite flows, tuffs, domes, and shallow intrusions containing phenocrysts of quartz, sanidine, and biotite. The Peralta Tuff Member is mostly bedded air-fall tuffs, but includes hct avalanche deposits and some stream-reworked tiuffs. The age of the Bearhead Rhyolite is late Miocene.

\section{E. Cochiti Formation 9,41}

The Cochiti Formation is a thick $(460 \mathrm{~m})$ sequence of basalt, andesite, dacite, and rhyolite gravel and sand derived from penecontemporaneous erosion of Keres Group rocks. The formation is repeated by faulting and its full thickness is not exposed. The Cochiti Formation is late Miocene in age.

\section{POLVADERA GROUP ${ }^{41}$}

The late Miocene to late Pliocene Polvadera Group is a sequence of basaltic, andesitic, dacitic, and rhyolitic rocks occurring in the central and northern Jemez Mountains. Total thickness is about $1500 \mathrm{~m}$ but only about $1100 \mathrm{~m}$ are exposed in any one place. Radiometric age dates range from 7.4 to $2.0 \mathrm{Myr}$.

\section{A. Lobato Basalt ${ }^{9,41}$}

The Lobato Basalt, named for Lobato Mesa, consists of many basalt flows, 6 to $15 \mathrm{~m}$ in thickness, that form inesas in the northern and northeastern Jemez Mountains. The flows are mostly olivine-augite basalts but include titaniferous augite-, hypersthene- and pigeonite-bearing basalts and often xenocrysts of quartz. Maximum thickness is about $180 \mathrm{~m}$. The formation has been dated radiometrically as about $7.4 \mathrm{Myr}$ old.

\section{B. Tschicoma Fornation ${ }^{9: 0,41}$}

The Tschicoma Formation, forming the major part of the interior mass of the central mountains, consists mostly of porphyritic dacite, rhyodacite, and quartz latite containing phenocrysts of pyroxene, hornblende, 
biotite, plagioclase, and quartz. Exposures of andesite and rhyolite also occur. Some units of quartz latite and latite in the Los Alamos area contain xenocrystic plagioclase that has been partially melted, embayed, and resorbed, as well as subrounded and embayed quartz. Maximum thickness exceeds $900 \mathrm{~m}$. The Tschicoma Formation has been dated by radiometric methods as 6.7 to $3.7 \mathrm{Myr}$ old.

\section{El Rechuelos Rhyolite ${ }^{9.41}$}

The El Rechuelos Rhyolite occurs as a series of small rhyolite domes and a pumice cone in the northern Jemez Mountains. The formation consists of pumiceous and lithic rhyolite, pumice, perlite, and obsidian containing a few phenocrysts of quartz and sanidine. Radiometric dating indicates an age of at least 2 Myr.

\section{PUYE FORMATION ${ }^{9,41}$}

The Puye Formation, named for exposures in cliffs along the Puye Escarpment, is a poorly consolidated, silty, sandy, conglomerate containing interlayered lithic lapilli-tuff beds and lahar deposits. The detritus is mostly dacite, rhyodacite, and quartz latite debris derived from erosion of the Tschicoma Formation.

The basal Totavi Lentil ( 0 to $25 \mathrm{~m}$ thick) consists of well-rounded pebbles, cobbles, and boulders of Precambrian quartzite and granite in a matrix of coarse arkosic sandstone.

The thickness of the Puye Formation is about $15 \mathrm{~m}$ in the eastern part of Pajarito Plateau and thickens westward to about $220 \mathrm{~m}$.

\section{VOLCANIC ROCKS OF EL ALTO, CERROS DEL RIO, AND SANTA ANA MESA ${ }^{9}$}

The El Alto yolcanics, in the northern Jemez, are olivine-augite basalts and cinders up to $60 \mathrm{~m}$ thick containing xenocrysts of quartz.

The volcanics of Cerros del Rio are mostly basaltic andesite flows and tuffs ( 0 to $460 \mathrm{~m}$ thick) containing xenocrysts of quartz. Griggs ${ }^{i 0}$ described five units in the Los Alamos area.

The rocks of Santa Ana Mesa are olivine-augite basalt flows and scoriaceous pyroclastics up to $300 \mathrm{~m}$ thick. These rocks are less than $2.8 \mathrm{Myr}$ old. ${ }^{43.44}$

\section{BASALTIC ANDESITE OF TANK NINETEEN ${ }^{9}$}

These basaltic andesite flows form a broad shield volcano in the western part of the Cerros del Rio. In the lower part of White Rock Canyon they overlie the Otowi Member of the Bandelier Tuff and the Cerro Toledo Rhyolite. Thickness ranges from 15 to $150 \mathrm{~m}$.

\section{TEWA GROUP ${ }^{41,45}$}

The Pleistocene Tewa Group, as defined by Griggs, ${ }^{10}$ includes a series of rhyolite and quartz latite domes, ash flows, air-fall pumice, and obsidian, representing the most recent stages of volcanism and caldera collapse in the Jemez Mountains. Ages range from 1.4 to about 0.04 Myr old.

\section{A. Bandelier Tuff $2,9,45,72$}

The Bandelier Tuff comprises a sequence of nonwelded to densely welded rhyolite ash flows and pumice containing bi-pyramidal quartz and chatoyant sanidine. The tuff forms the Jemez Plateau on the western, and the Pajarito Plateau on the eastern, flanks of the Jemez Mountains. The formation is divided into two members, the lower Otowi and upper Tshirege, locally separated by tuffs of the Cerro Toledo Rhyolite. Each member is associated with a separate caldera collapse event and is composed of a basal air-fall pumice overlain by a series of ash-flow units. The Bandelier Tuff ranges in thickness from 10 to $320 \mathrm{~m}$.

\section{Otowi Member $2.9,45,72$}

The 1.4-Myr-old Otowi Member, associated with the Toledo caldera, consists of a 0 - to 10-m-thick basal-bedded air-fall pumice (Guaje Pumice Bed) overlain by nonwelded to densely welded ash-flow deposits containing abundant accidental lithic fragments. Ash-flow units in the Otowi are often easily eroded to form characteristic pinnacle-shaped features locally called "tent rocks." The thickness of this member ranges from 0 to $180 \mathrm{~m}$. 


\section{Tshirege Member ${ }^{2,9,45,72}$}

The 1.1-Myr-old Tshirege Member is associated with the Valles caldera, which post-dates and truncates the Valle Toledo. The member consists of a $0.3-\mathrm{m}$-thick basal bedded air-fall pumice (Tsankawi Pumice Bed) overlain by a sequence of nonwelded to densely welded ash flows containing inclusions of genetically-related hornblende-rich quartz latite pumice and accidental lithic fragments. The Tshirege Member ranges from 15 to 270 $\mathrm{m}$ thick.

\section{B. Cerro Toledo Rhyolite ${ }^{9,41}$}

The Cerro Toledo Rhyolite is a series of post-collapse rhyolite domes, obsidian, tuffs, and tuff breccias associated with the 1.4-Myr-old Toledo caldera. The massive rhyolite is often lithophysal and contains phenocrysts of sanidine and, occasionally, quartz. The pyroclastic deposits ( 0 to $60 \mathrm{~m}$ thick) include some nuee ardente deposits erupted from the Rabbit Mountain vent.

\section{Cerro Rubio Quartz Latite 9.41}

The Cerro Rubio Quartz Latite consists of domes and shallow intrusions of biotite-hornblende quartz latite occurring in the Valles caldera.

\section{Valles Rhyolite $e^{9,41}$}

The Pleistocene to Holocene Valles Rhyolite is a series of post-collapse rhyolite domes, flows, tuffs, tuff breccias, and obsidian erupted within the Valles caldera.

\section{Deer Canyon Member}

The Deer Canyon Member consists of a rhyolite dome flow and associated bedded tuffs and breccias (10 to 30 $m$ thick). The rhyolite is coarsely porphyritic, containing sanidine and bi-pyramidal quartz, and lacking ferromagnesian minerals.

\section{Redondo Creek Member}

This member includes a rhyolite dome, flows, dikes, and up to $150 \mathrm{~m}$ of interlayered tuffs and perlitic flow breccias, characterized by sanidine-rimmed plagioclase, pyroxene, biotite, and lacking quartz.

\section{Valle Grande Member}

The Valle Grande Member consists of rhyolite domes, flows (60 to $760 \mathrm{~m}$ thick), and bedded tuffs and tuff breccias (0-150 m thick). The porphyritic rhyolite contains major sanidine and quartz, and minor plagioclase, biotite, hornblende, and pyroxene. Phenocrysts occur only in domes in the western and southern parts of the caldera. Those in the eastern portion are phenocryst-free. The Valle Grandc Member is 0.4 to $1.0 \mathrm{Myr}$ old.

\section{Battleship Rock Member}

The Battleship Rock Member consists of nonwelded to partly welded rhyolite ash flows and pumice lapilli and blocks, containing phenocrysts of quartz, sanidine, hornblende, plagioclase, and pyroxene. These flows, 15 to $120 \mathrm{~m}$ thick, probably erupted from a vent near El Cajete.

\section{El Cajete Member}

The El Cajete Member is a sequence of well to poorly bedaed air-fall block and lapilli pumice containing quartz, sanidine, plagiociase, hornblende, biotite, and pyroxene. This member ranges from 0 to $75 \mathrm{~m}$ thick in the Valles caldera, but a thin scattering of pumice occurs as much as $50 \mathrm{~km}$ away. The El Cajete is probably greater than 42000 yr old.

\section{Banco Bonito Member}

The Banco Bonito Member is a 30 to $150 \mathrm{~m}$ thick flow of porphyritic obsidian containing phenocrysts of quartz, sanidine, plagioclase, biotite, hornblende, and pyroxene. The source vent is just west of El Cajete. 


\section{APPENDIX C \\ ENERGY OF VOLCANIC ERUPTIONS}

It is often useful to compare the relative strengths of volcanic eruptions, both for different volcanoes and for different eruptions at the same location. The relative strength of an eruption can be estimated by one of several methods. Eruption intensity ${ }^{73}$ is based on the volume of ejected material. In the Jemez Mountains, each of the caldera-forming eruption sequences deposited about $300 \mathrm{~km}^{3}$ of material around the flanks of the volcano, not counting an unknown volume of ash that may have fallen as far away as Iowa and Illinois. ${ }^{74}$ As shown in Table C-I, each of these events may be classified as Intensity IX.

A quantity that is more useful, however, is the amount of energy released during an eruption. There are many forms of energy associated with an eruption, including the kinetic energy of the ejected material, the potential energy related to the height of the magma column in the vent, the energy of volcanic earthquakes, and thermal energy released during the eruption. ${ }^{75}$ Many of these may be extremely difficult to quantify without directly observing the eruption, but an approximate energy estimate can often be obtained. Yokoyama ${ }^{75}$ reported that thermal energy is 10 to 100 times greater than any other kind and may be used to approximate the total energy release. The thermal energy $E_{t h}$ for an eruption is given by

$E_{t h}=V_{\sigma}(T \alpha+\beta) J$,

where $\mathrm{V}$ is the volume of the ejected material, $\sigma$ is the specific heat of lava $\left(0.25 \mathrm{cal} / \mathrm{g} /{ }^{\circ} \mathrm{C}\right), \beta$ is the latent heat of lava ( $50 \mathrm{cal} / \mathrm{g}$ ), and $J$ is the equivalent work of heat in joules. ${ }^{73,76}$ For the case of a pyroclastic eruption, such as those that produced the Bandelier Tuff, the above equation reduces to

$E_{\text {th }}=\mathrm{V} \sigma \mathrm{T} \alpha$.

Assuming a density $\sigma$ of $1.6 \mathrm{~g} / \mathrm{cm}^{3}$ and a temperature $\mathrm{T}$ of about $600^{\circ} \mathrm{C}$, then $E_{\text {th }} \simeq 5.9 \times 10^{20}$ joules for each of the caldera-forming eruptive sequences. This is equal to $1.4 \times 10^{11}$ nuclear equivalent tons of TNT. Large caldera-forming eruptions cannot be rigorously com-
TABLE C-I

\section{INTENSITY OF VOLCANIC ERUPTIONS ${ }^{a}$}

\begin{tabular}{|c|c|}
\hline Intensity & $\begin{array}{l}\text { Volume of Ejecta } \\
\qquad\left(\mathrm{km}^{3}\right)\end{array}$ \\
\hline IX & $>100$ \\
\hline VIII & $10-100$ \\
\hline VII & $1-10$ \\
\hline vI & $0.1-1.0$ \\
\hline$v$ & $0.01-0.1$ \\
\hline IV & $0.001-0.01$ \\
\hline III & $0.0001-0.001$ \\
\hline II & $0.00001-0.0001$ \\
\hline I & $<0.00001$ \\
\hline 0 & 0 (fumaroles only) \\
\hline
\end{tabular}

pared to other kinds of eruptions, but, as none have ever been observed, it may be instructive in a general way to compare the energies released by several volcanoes (Table C-II).

Using earthquake magnitudes as a model, Hedervari ${ }^{76}$ developed an equivalent eruption magnitude $M_{e}$. Eruption magnitude is a function of the volume and density of the ejecta, whereas therm ${ }^{-1}$ energy is related to temperature. The earthquake energy-magnitude relation

$\log E=11+1.6 \mathrm{M}$,

where $E$ is the energy released during an earthquake and $M$ is the earthquake magnitude, may be rewritten in terms of volcano-related parameters as

$\mathrm{M}_{\mathrm{e}}=\frac{\log (\mathrm{V} \sigma \mathrm{T} \alpha \mathrm{J})-11}{1.6}$

Substituting with the assumptions used in the thermal energy calculation above, the eruption magnitude for each of the caldera-forming eruptions in the Jemez Mountains is magnitude 10.5 (Table C-II). 
TABLE C-II

ENERGY AND MAGNITUDES OF ERUPTIONS ${ }^{a}$

\begin{tabular}{|c|c|c|c|c|c|c|}
\hline Intensity & Volcano & Year & Type $^{b}$ & $\begin{array}{c}\text { Volume of } \\
\text { Ejecta } \\
\left(\mathrm{km}^{3}\right)\end{array}$ & $\begin{array}{c}\text { Thermal } \\
\text { Energy } \\
\text { (J) }\end{array}$ & $\begin{array}{c}\text { Eruption } \\
\text { Magnitude }\end{array}$ \\
\hline IX & Valles, New Mexico & $1.1 \mathrm{Myr}$ & B & 300 & $5.9 \times 10^{20}$ & 10.5 \\
\hline IX & Tambora, Sumbawa & 1815 & B & 150 & $1.4 \times 10^{20}$ & 10.1 \\
\hline VII & Katmai, Alaska & 1912 & B & 21 & $2.0 \times 10^{19}$ & 9.6 \\
\hline VIII & Krakatoa, Indonesia & 1883 & B & 18 & $1.8 \times 10^{19}$ & 9.5 \\
\hline VI & Hecla, Iceland & $1947-48$ & A & 0.4 & $1.3 \times 10^{18}$ & 8.8 \\
\hline VI & Kilauca, Hawaii & 1960 & $\mathbf{A}$ & 0.16 & $5.9 \times 10^{17}$ & 8.6 \\
\hline VI & Taal, Luzon & 1911 & $\mathrm{C}$ & 0.5 & $4.8 \times 10^{17}$ & 8.6 \\
\hline $\mathrm{V}$ & Teneriff, Canary Islands & 1909 & $\mathrm{~A}$ & 0.015 & $4.7 \times 10^{16}$ & 7.9 \\
\hline IV & Etna. Sicily & 1955 & $A, B$ & 0.004 & $1.4 \times 10^{16}$ & 7.6 \\
\hline II & liha Nova, Azores & 1957 & $\mathbf{B}$ & 0.00002 & $1.9 \times 10^{16}$ & 5.8 \\
\hline
\end{tabular}

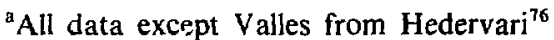

${ }^{\mathrm{b}} \mathrm{A}=$ lava flows, $\quad \mathbf{B}=$ pyroclastic ejecta, $\quad \mathrm{C}=$ old fragments

\section{REFERENCES}

1. C. A. Newton, D. J. Cash, K. H. Olsen, and E. F. Homuth, "LASL Seismic Programs in the Vicinity of Los Alamos, New Mexico," Los Alamos National Laboratory report LA-6406-MS (November 1976).

2. C. S. Ross, R. L. Smith, and R. A. Bailey, "Outline of the Geology of the Jemez Mountains, New Mexico," in New Mexico Geo. Soc. Twelfth Field Conf., Albuquerque Country (1961) pp.139-143.

3. D. J. Cash, N. J. McFarland, and J. J. Headdy, "Seismicity of Northern New Mexico, 1973-1978," Los Alamos National Laboratory report LA-7575-MS (1978).
4. C. E. Chapin, "Evolution of the Rio Grande Rift, A Summary," in Rio Grande Rift: Tectonics and Magmatism, R. E. Riecker, Ed.(Amer. Geophys. Union, Washington, D.C., 1979), pp. 1-5.

5. W. S. Baldridge, "Petrology and Petrogenesis of Plio-Pleistocene Basaltic Rocks from the Central Rio Grande Rift, New Mexico, and Their Relation to Rift Structure," in Rio Grande Rift: Tectonics and Magmatism, R. E. Riecker, Ed. (Amer. Geophys. Union, Washington, D.C., 1979), pp. 323-353.

6. W. R. Seager and P. Morgan, "Rio Grande Rift in Southern New Mexico, West Texas, and Northern Chihuahua," in Rio Grande Rift: Tectonics and Magmatism, R. E. Riecker, Ed. (Amer. Geophys. Union, Washington, D.C., 1979), pp. 87-106. 
7. R. G. Luedke and R. L. Smith, "Map Showing Distribution, Composition, and Age of Late Cenozoic Volcanic Centers in Arizona and New Mexico," U. S. Geol. Survey Map 1-1091-A (1978).

8. R. L. Smith, R. A. Bailey, and S. L. Russell, "The Volcanic Evolution of the Jemez Mountains, and its Relationship to the Rio Grande Rift," in "1978 International Symposium on the Rio Grande Rift, October 8-17, 1978, Santa Fe, New Mexico," Los Alamos National Laboratory report LA-7487-C (September 1978), pp. 91-92.

9. R. L. Smith, R. A. Bailey, and C. S. Ross, "Geologic Map of the Jemez Mountains, New Mexico," U.S. Geol. Survey Misc. Geol. Investigation Map I-571 (1970).

10. R. L. Griggs, "Geology and Ground Water, Los Alamos Area, New Mexico," U. S. Geol. Survey Water Supply Paper 1753 (1964).

11. M. A. Rogers, "History and Environmental Setting of LASL Near-Surface Land Disposal Facilities for Radioactive Wastes (Areas A, B, C, D, E, F, G, and T): A Source Document," Los Alamos National Laboratory report LA-6848-MS, Vol. I (1977).

12. W. D. Purtymun and W. R. Kennedy, "Geology and Hydrology of Mesita del Buey," Los Alamos National Laboratory repori LA-4660 (May 1971).

13. M. Wheeler, A. Gallegos, W. Whitty, G. Maestas, W. J. Smith, and B. Perkins, "Evaluation of Transuranic-Contaminated Radioactive Waste Disposal Areas," in "Transuranic Solid Waste Management Programs, July-December 1974," Los Alamos National Laboratory report LA-6100-PR (October 1975), pp. 15-38.

14. A. J. Budding and W. D. Purtymun, "Seismicity of the Los Alamos Area Based on Geologic Data," Los Alamos National Laboratory report LA-6278-MS (1976).

15. A. R. Sanford, "Seismicity of the Los Alamos Region Based on Seismological Data," Los Alamos National Laboratory report LA-6416-MS (July 1976).
16. M. L. Wheeler, W. J. Smith, and A. F. Gallegos, "A Preliminary Evaluation of the Potential for Plutonium Release from Burial Grounds at Los Alamos Scientific Laboratory," Los Alamos National Laboratory report LA-6694-MS (February 1977).

17. T. T. Fujita, "Estimate of Maximum Windspeeds of Tornadoes in Southernmost Rockies," Satellite and Mesometeorology Research Project research paper No. 105 (1972).

18. W. V. Abeele, "Future Credible Precipitation Occurrences in Los Alamos, New Mexico," Los Alamos National Laboratory report LA-8523-MS (September 1980).

19. G. P. Eaton, "A Plate-Tectonic Model for Late Cenozoic Crustal Spreading in the Western United States," in Rio Grande Rift: Tectonics and Magmatism, R. E. Riecker, Ed. (Amer. Geophys. Union, Washington, D.C.,1979), pp. 7-32.

20. T. Atwater, "Implications of Plate Tectonics for the Cenozoic Tectonic Evolution of Western North America," Geol. Soc. Bull., 81,3513-3536 (1970).

21. L. W. Mintz, Historical Geology: The Science of a Dynamic Earth (Charles E. Merrill Publ. Co., Columbus, Ohio 1972), pp. 653-659.

22. W. E. Elston and T. J. Bornhorst, "The Rio Grande Rift in Context of Post-40 MY Volcanic and Tectonic Events," in Rio Grande Rift: Tectonics and Magmatism, R. E. Riecker, Ed. (Amer. Geophys. Union, Washington, D.C., 1979) pp. 416-438.

23. J. F. Hermance and J. Pedersen, "Deep Structure of the Rio Grande Rift. A Magnetotelluric Intepretation," in "International Symposium on the Rio Grande Rift, Oct. 8-17, 1978, Santa Fe, New Mexico," Los Alamos National Laboratory report LA-7487-C (September 1978), pp. 41-42.

24. L. Cordell, "Overview of Geophysical Studies in the Rio Grande Rift," in "International Symposium on the Rio Grande Rift, Oct. 8-17, 1978, Santa Fe, New Mexico," Los Alamos National Laboratory report LA-7487-C (September 1978), pp. 28-29. 
25. P. W. Lipman and H. H. Mehnert, "The Taos Plateau Volcanic Field, Northern Rio Grande Rift, New Mexico," in Rio Grande Rift: Tectonics and Magmatism, R. E. Riecker, Ed. (Amer. Geophys. Union, Washington, D.C., 1979) pp. 289-311.

26. K. Manley, "Stratigraphy and Structure of the Española Basin, Rio Grande Rift, New Mexico," in Rio Grande Rift: Tectonics and Magmatism, R. E. Riecker, Ed. (Amer. Geophys. Union, Washington, D.C., 1979) pp. 71-86.

27. D. G. Brookins, R. B. Forbes, D. L. Turner, A. W. Laughlin, and C. W. Naeser, "Rb-Sr, K-Ar, and Fission-Track Geochronological Studies of Samples from LASL Drill Holes GT-1, GT-2, and EE-1," Los Alamos National Laboratory report LA-6829-MS (June 1977).

28. D. L. Smith and R. L. Jones, "Thermal Anomaly in Northern Mexico: Ar Extension of the Rio Grande Rift?," in Rio Grande Rift: Tectonics and Magmatism, R. E. Riecker, Ed. (Amer. Geophys. Union, Washington, D.C., 1979) pp. 57-70.

29. L. Cordell, "Gravimetric Expression of Graben Faulting in Santa $\mathrm{Fe}$ County and the Española Basin, New Mexico," in New Mexico Geol. Soc. Thirtieth Field Conf., Santa Fe Country (1979), pp. 59-64.

30. V. C. Kelley, "Tectonics, Middle Rio Grande Rift, New Mexico," in Rio Grande Rift: Tectonics and Magmatism, R. E. Riecker, Ed. (Amer. Geophys. Union, Washington, D.C., 1979) pp. 57-70.

31. V. C. Kelley, "Geology of Española Basin, New Mexico," New Mexico Bur. Mines and Min. Resources Geologic Map 48 (1978).

32. D. B. Slemnıons, "Fault Activity and Seismicity Near the Los Alamos Scientific Laboratory Geothermal Test Site, Jemez Mountains, New Mexico," Los Alamos National Laboratory report LA-5911-MS (April 1975).

33. W. R. Muehlberger, "The Embudo Fault Between Pilar and Arroyo Hondo, New Mexico; An Active Intracontinental Transform Fault," in New Mexico Geol. Soc. Thirtieth Field Conf., Santa Fe Country (1979) pp. 77-82.
34. A. J. Budding and C. A. Beers, "Faults in the Los Alamos Area and Their Relation to Seismicity," internal Los Alamos National Laboratory report (1972).

35. A. R. Sanford, K. H. Olsen, and L. H. Jaksha, "Seismicity of the Rio Grande Rift," in Rio Grande Rift; Tectonics and Magmatism, R. E. Riecker, Ed. (Amer. Geophys. Union, Washington, D.C. 1979), pp. 145-168.

36. J. C. Aubele, "The Cerros del Rio Volcanic Field," in New Mexico Geol. Soc. Thirtieth Field Conf., Santa Fe Country (1979), pp. 243-252.

37. C. A. Zimmerman and A. M. Kudo, "Geology and Petrology of Tetilla Peak, Santa Fe County, New Mexico," in New Mexico Geol. Soc. Thirtieth Field Conf., Santa Fe Country (1979), pp. 253-256.

38. K. H. Olsen, G. R. Keller, and J. N. Steward, "Crustal Structure Along the Rio Grande Rift from Seismic Refraction Profiles," in Rio Grande Rift: Tectonics and Magmatism, R. E. Riecker, Ed. (Amer. Geophys. Union, Washington, D.C., 1979), pp. 127-143.

39. R. L. Smith, "Ash Flow Magmatism," in "Ash Flow Tuffs," C. E. Chapin and W. E. Elston, Eds., Gec!. Soc. Amer. Special Paper 180 (1979), pp. 5-27.

40. R. L. Smith, R. A. Bailey, and C. S. Ross, "Structural Evolution of the Valles Caldera, New Mexico and Its Bearing on the Emplacement of Ring Dikes," U. S. Geol. Survey Professional Paper 424-D, pp. D145-149 (1961).

41. R. A. Bailey, R. L. Smith, and C. S. Ross, "Stratigraphic Nomenclature of Volcanic Rocks in the Jemez Mountains, New Mexico," U. S. Geol. Survey Bull. 1274-P (1969).

42. R. L. Smith and R. A. Bailey, "Resurgent Cauldrons," in "Studies in Volcanology," Geol. Soc. Amer. Memoir 116, (1968) pp. 613-662.

43. K. Manley, "K-Ar Age Determinations on Pliocene Basalts from the Española Basin, New Mexico," Isochron/West 16, 29-30 (1976). 
44. G. O. Bachman and H. H. Mehnent, "New K-Ar Dates and the Late Pliocene to Holocene Geomorphic History of the Central Rio Grande Region, New Mexico," Geol. Soc. Amer. Bull. 89, 283-292 (1978).

45. R. R. Doell, G. B. Dalrymple, R. L. Smith, and R. A. Bailey, "Paleomagnetism, Potassium-Argon Ages, and Geology of Rhyolites and Associated Rocks of the Valles Caldera, New Mexico," in "Studies in Volcanology," Geol. Soc. Amer. Memoir 116. (1968) pp. 211-248.

46. J. G. Moore and W. G. Melson, "Nuées Ardentes of the 1968 Eruption of Mayon Volcano, Phillippines," Bull. Volcanologique, 33. 337-363 (1969).

47. W. D. Rose, Jr., "Pattern and Mechanism of Volcanic Activity at the Santiaquito Volcanic Dome, Guatemala," Bull. Volcanologique, 37, 73-94 (1973).

48. Z. G. Woodruff and W. D. Rose, Jr., "Pattern of Historic Activity at Volcan Fuego, Guaiemala," EOS (Amer. Geophys. Union Transactions), 57, 345 (1976).

49. M. F. Sheridan, "Emplacement of Pyroclastic Flows: A Review," in "Ash Flow Tuffs," C. E. Chapin and W. E. Elston, Eds., Geol. Soc. Amer. Special Paper 180, pp. 125-136 (1979).

50. R. S. J. Sparks, L. Wilson, and G. Hulme, "Theoretical Modeling of the Generation Movement and Emplacement of Pyroclastic Flows by Column Collapse," Jour. Geophys. Research, 83, No. B4, 1727-1739 (1978).

51. F. G. West, "Regional Geology and Geophysics of the Jemez Mountains," Los Alamos National Laboratory report LA-5362-MS (August 1973).

52. F. J. Hermance, "Toward Assessing the Geothermal Potential of the Jemez Mountains Volcanic Complex: A Telluric-Magnetotelluric Survey," Los Alamos National Laboratory report LA-7657-MS (February 1979).

53. C. Ollier, Volcanoes (MIT Press, Cambridge, Massachusetts 1969), pp. 15, 154-155.
54. B. Stewart, "Prelude: March 20 to May 17, 1980," in "Mount St. Helens Diary," The Columbian, Inc., Vancouver, Washington (May 1980).

55. K. H. Olsen, "The Seismicity of North-Central New Mexico with Particular Reference to the Cerrillos Earthquake of May 20, 1918," in New Mexico Geol. Soc. Thirtieth Field Conf., Santa Fe Country (1979), pp. 65-75.

56. R. E. Reilinger, L. D. Brown, and J. E. Oliver. "Recent Vertical Crustal Movements from Leveling Observations in the Vicinity of the Rio Grande Rift," in Rio Grande Rift: Tectonics and Magmatism, R. E. Riecker, Ed. (Amer. Geophys. Union, Washington, D.C., 1979), pp. 223-236.

57. M. Reiter, C. L. Edwards, H. Hartman, and C. Weidman, "Terrestrial Heat Flow Along the Rio Grande Rift, New Mexico and Southern Colorado," Geol. Soc. Amer. Bull., 81 1-818 (1975).

58. National Academy of Science for the American Geological Instituie, Dictionary of Geological Terms (1962).

59. M. A. Reiter, A. J. Mansure, and C. Shearer, "Geothermal Characteristics of the Rio Grande Rift Within the Southern Rocky Mountains Complex," in Rio Grande Rift: Tectonics and Magmatism, $\mathbf{R}$. E. Ricker, Ed. (Amer. Geophys. Union, Washington, D.C., 1979), pp. 253-267.

60. R. H. Hendron, "Energy Extraction Operations: Some Preliminary Results," Pressure Vessels and Piping Conference, San Francisco, California, June 25-29, 1979 (Pressure Vessels and Piping Division of the American Society of Mechanical Engineers, 1979).

61. Williston, McNeil and Associates, Lakewood, Colorado, "A Time Domain Survey of the Los Alamos Region, New Mexico," Los Alamos National Laboratory report LA-7657-MS (1979).

62. "Environmental and Other Evaluations of Alternatives for Long-Term Management of Buried INEL Transuranic Waste," Idaho National Engineering Laboratory report IDO-10085 (1979). 
63. S. E. Logan and M. C. Berbano, "Development and Application of Risk Assessment Method for Radioactive Waste Management. Vol. III: Implementation of Terminal Storage in Reference Repository and Other Applications. Appendix C," Environmental Protection Agency report EPA-520-520/6-78-005 (1978).

64. B. M. Crowe, "Research and Development Related to the Nevada Nuclear Waste Storage Investigations, October 1 - December 31, 1979," Los Alamos National Laboratory report LA-8309-PR (April 1980).

65. T. H. Smith, "Data for Frequency of New Volcanoes," Advanced Waste Management Studies Progess Report, Battelle Northwest Laboratory report BNWL-B-223-10 (1974).

66. F. J. Dewey, "Plate Tectonics," in Readings from Scientific American, Planet Earth, pp. 124-135 (1972).

67. T. W. Lambe, "Predictions in Soil Engineering," Geotechnique, 23, No. 2, 149-202 (1973).

68. C. H. Dowding and J. B. Miller, Comparison of Predicted and Encountered Geology for 7 Colorado Tunnels (MIT, Cambridge, Massachusetts, 1975).

69. A. C. Miegh, "The Triassic Rocks, with Particular Reference to Predicted and Observed Performance of Some Major Foundation," Geotechnique, Vol. 26, No. 3, 391-452 (1976).
70. Geological Society of London, "The Phanerozoic Time Scale, A Symposium," Geol. Soc. London, Quarterly Journal, 120, Suppl.. 260-73 (1964).

71. W. A. Berggren, "A Cenozoic Time Scale-Some Implications for Regional Geology and Pajeobiogeography," Zethaia, 5, No. 2, 195-215 (1972).

72. B. M. Crowe, G. W. Linn, G. Heiken, and M. L. Bevier, "Stratigraphy of the Bandelier Tuff in the Pajarito Plateau, Applications to Waste Management," Los Alamos National Laboratory report LA-7225-MS (1978).

73. H. Tsuya, "Geological and Petrological Studies of Volcano Fuji, Part 5: On the 1707 Eruption of Volcano Fuji," Bull. of the Earthquake Research Inst., University of Tokyo, 33, Part 3, 341-393 (1955).

74. R. E. Riecker, "Plate Tectonics-Where the Action is," Los Alamos Science, 1, No. 1, 140-145 (1980).

75. S. Yokoyama, "Energetics in Active Volcanoes, 1st Paper," Bull. of the Earthquake Research Inst., University of Tokyo, 34, 185-195 (1956).

76. P. Hedervari, "On the Energy and Magnitude of Volcanic Eruptions," Bull. Volcanologique, Ser. 22. 372-383 (1973). 